\section{Pacific Northwest}

National Laboratory

Operated by Battelle for the

U.S. Department of Energy-

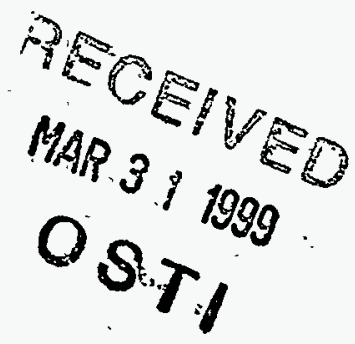

\title{
Borehole Data Package for 1998 Wells Installed at Single-Shell Tank Waste Management Area $\mathrm{U}$
}

D. G. Horton

F. N. Hodges

March 1999

Prepared for the U.S. Department of Energy under Contract DE-AC06-76RLO 1830 


\section{DISCLAIMER}

This report was prepared as an account of work sponsored by an agency of the United States Government. Reference herein to any specific commercial product, process, or service by trade name; trademark, manufacturer, or otherwise does not necessarily constitute or imply its endorsement, recommendation, or favoring by the United States, Government or any agency thereof, or Battelle Memorial Institute.

\section{PACIFIC NORTHWEST NATIONAL LABORATORY operated by \\ BATTELLE \\ for the \\ UNITED STATES DEPARTMENT OF ENERGY under Contract DE-AC06-76RLO 1830}

\section{Printed in the United States of America}

Available to DOE and DOE contractors from the Office of Scientific and Technical Information, P.O. Box 62, Oak Ridge, TN 37831; prices available from (615) 576-8401:

Available to the public from the National Tectinical Information Service, U.S. Department of Commerce, 5285 Port Royal Rd., Springfield, VA 22161 


\section{DISCLAIMER}

This report was prepared as an account of work sponsored by an agency of the United States Government. Neither the United States Government nor any agency thereof, nor any of their employees, make any warranty, express or implied, or assumes any legal liability or responsibility for the accuracy, completeness, or usefulness of any information, apparatus, product, or process disclosed, or represents that its use would not infringe privately owned rights. Reference herein to any specific commercial product, process, or service by trade name, trademark, manufacturer, or otherwise does not necessarily constitute or imply its endorsement, recommendation, or favoring by the United States Government or any agency thereof. The views and opinions of authors expressed herein do not necessarily state or reflect those of the United States Government or any agency thereof. 


\section{DISCLAIMER}

Portions of this document may be illegible in electronic image products. Images are produced from the best available original document. 


\section{Borehole Data Package for 1998 Wells Installed at Single-Shell Tank Waste Management Area U}

D. G. Horton

F. N. Hodges

March 1999

Prepared for

the U.S. Department of Energy

under Contract DE-AC06-76RLO 1830

Pacific Northwest National Laboratory

Richland, Washington 99352 


$$
\ldots \ldots
$$




\section{Acknowledgment}

The analysis of particle size distribution, moisture content, calcium carbonate content, $\mathrm{pH}$, electrical conductivity, cation exchange capacity, and alkalinity.were done in the Applied Geology and Geochemistry Group laboratory, Pacific Northwest National Laboratory, Richland, Washington. The work was supervised by Jeff Serne. His laboratory also produced the 1:1 water:sediment extracts for major cation and anion analyses. The cation analyses were done at the Chemical Analysis Laboratory at the University of Georgia in Athens, Georgia. The anion analyses were done in the Pacific Northwest National Laboratory interfacial geochemistry laboratory. Mr. Serne provided interpretations of the physical and chemical data from sediment samples, and those interpretations are incorporated into this report. His contribution is very much appreciated. 



\section{Contents}

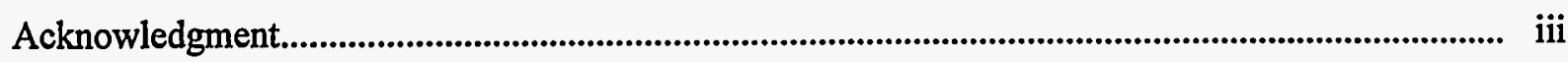

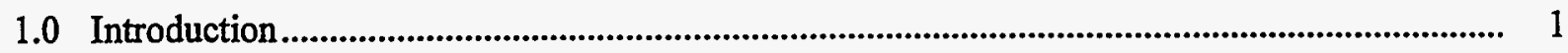

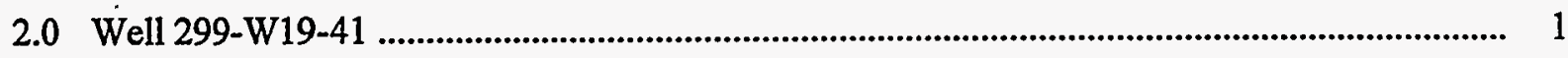

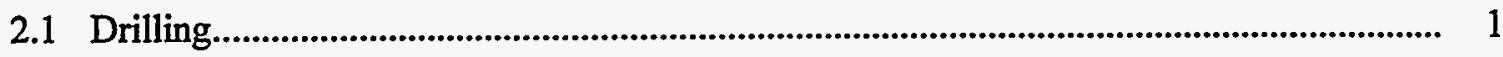

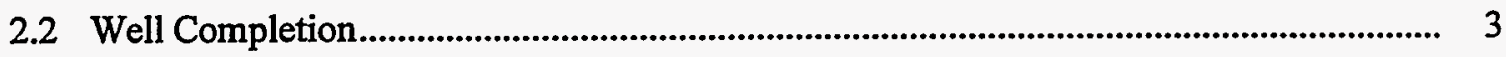

2.3 Well Development and Pump Installation ................................................................. 3

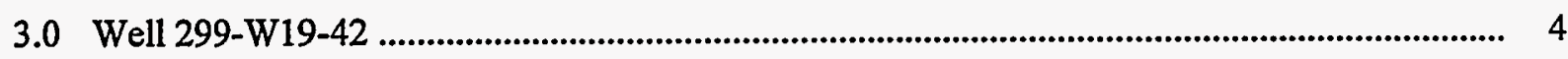

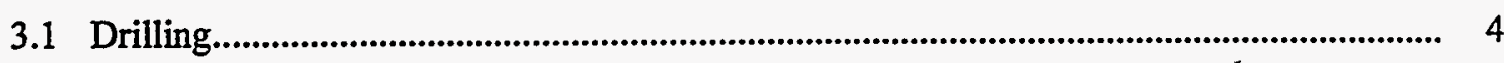

3.2 Well Completion......................................................................................................... 5

3.3 Well Development and Pump Installation .................................................................. 5

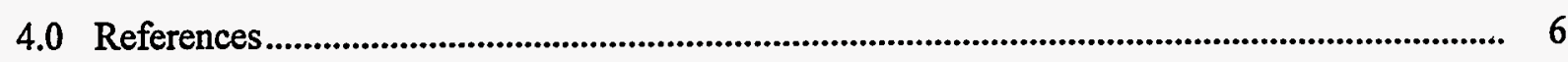

Appendix A - Well Construction and Completion Documentation................................................ A.1

Appendix B - Physical and Chemical Properties Data ............................................................... B.1

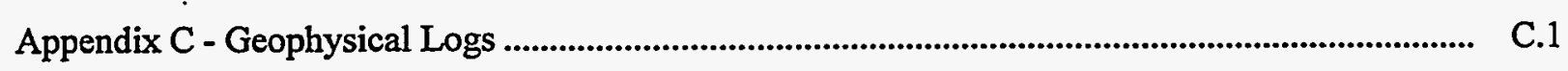

\section{Figure}

1 Map of Waste Management Area U and Locations of Wells in the Groundwater

Monitoring Network

\section{Table}

1 Survey Data for New Wells at Waste Management Area U 


\subsection{Introduction}

Two new Resource Conservation and Recovery Act (RCRA) groundwater monitoring wells were installed at the single-shell tank farm Waste Management Area (WMA) U in October 1998 in fulfillment of Tri-Party Agreement (Ecology 1996) milestone M-24-39. The wells are 299-W19-41 and 299-W19-42. Well 299-W19-41 is located east of the southeastern corner of the WMA and replaces downgradient well 299-W19-32. Well 299-W19-42 is located east of the WMA near the northeastern comer and is a new downgradient monitoring well. The locations of all wells in the monitoring network are shown on Figure 1.

The groundwater monitoring plan for WMA U (Caggiano and Goodwin 1991) describes the hydrogeology of the 200 West Area and WMA U. An Interim Change Notice to the groundwater monitoring plan provides justification for the new wells. The new wells were constructed to the specifications and requirements described in Washington Administrative Code (WAC) 173-160 and WAC 173-303.

This document compiles information on the drilling and construction, well development, pump installation, and sediment testing applicable to wells 299-W19-41 and 299-W19-42. Appendix A contains the geologist's log, the Well Construction Summary Report, and Well Summary Sheet (as-built diagram); Appendix B contains results of laboratory measurements of particle size distribution, $\mathrm{pH}$, conductivity, and calcium carbonate and moisture contents; and Appendix C contains geophysical logs. Aquifer tests (slug tests) were performed on both new wells. Results from the aquifer tests will be reported elsewhere. Additional documentation concerning well construction is on file with Bechtel Hanford, Inc., Richland Washington.

English units are used in this report because they are used by drillers to measure and report depths and well construction details. The conversion is made by multiplying feet by 0.3048 to obtain meters; or multiplying inches by 2.54 to obtain centimeters.

\subsection{Well 299-W19-41}

\subsection{Drilling}

Well 299-W19-41 was drilled using an air rotary rig. The well was drilled to a total depth of $264.5 \mathrm{ft}$ below ground surface (bgs) during September 1998. Temporary 8 5/8-in.-outside-diameter, carbon steel casing was used from ground surface to total depth. About 300 gal of water were added to the borehole at $264.5 \mathrm{ft}$ bgs to keep fine-grained sediment out of the casing. Static water level was $220.35 \mathrm{ft}$ bgs on September 23, 1998. 


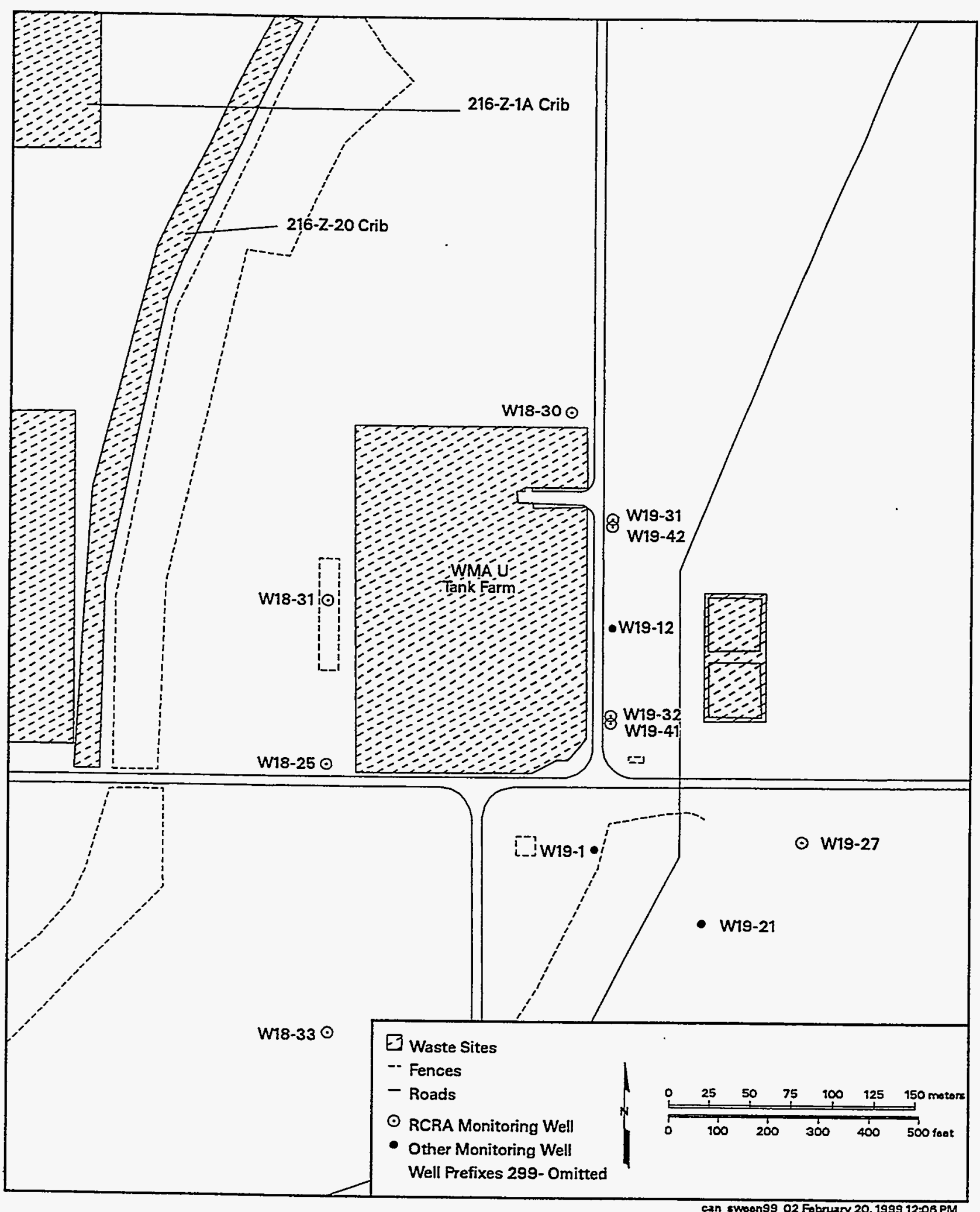

Figure 1. Map of Waste Management Area U and Locations of Wells in the Groundwater Monitoring Network 
Sediments encountered during drilling were predominantly sand to sandy gravel from the surface to about $127 \mathrm{ft}$ bgs. Silty sand and silty, sandy gravel were found from $127 \mathrm{ft}$ to total depth. A geologist's $\log$ is included in Appendix A.

Grab samples were collected at 29 and $69 \mathrm{ft}$ bgs for measurement of particle size distribution. Test results show that the sample from $29 \mathrm{ft}$ bgs is dominantly gravel with about 10 weight percent sand. The sample from $69 \mathrm{ft}$ bgs is sand. Particle size distribution data are in Appendix B. Additional grab samples were collected at 184 to $186 \mathrm{ft}$ and from 200 to $201 \mathrm{ft}$ bgs for analysis of residual contamination remaining on sediment surfaces from a declining water table. Those analyses have not been completed to date. Sediment samples also were collected for geologic description and archive at approximately 5-ft intervals.

The borehole and drill cuttings were monitored regularly for organic vapors and radionuclide contaminants. No contamination was noted.

\subsection{Well Completion}

The permanent casing and screen were installed in well 299-W19-41 in September 1998. A 4-in.inner-diameter, stainless steel, wire wrap (0.01 in. slot) screen was set from 255.14 to $220.05 \mathrm{ft}$ bgs. The permanent casing is 4-in.-inner-diameter stainless steel from $220.05 \mathrm{ft}$ bgs to $2.0 \mathrm{ft}$ above ground surface. Centralizers were placed at the top and bottom of the screen and every $40 \mathrm{ft}$ from the screen to the surface. The bottom of the screen has a 4 -in. end cap.

Silica sand (20-40 mesh) was placed around the screen and casing from 264.5 to $210.4 \mathrm{ft}$ bgs. The annular seal is medium bentonite chips from $210.4 \mathrm{ft}$ to $10.5 \mathrm{ft}$ bgs and Portland cement from $10.5 \mathrm{ft}$ to the surface. A carbon steel protective casing with locking cap covers the well. A $4 \mathrm{ft}$ by $4 \mathrm{ft}$ by 6 in. concrete pad was placed around the.well at the surface with four protective steel posts set into the concrete. A brass marker stamped with the well number was placed into the concrete. The Well Construction Summary Report and the Well Summary Sheet (as-built) are included in Appendix A.

The vertical and horizontal coordinates of the well were surveyed in December 1998. The horizontal position of the well was determined by global positioning system observations referenced to horizontal control stations established by the U.S. Army Corps of Engineers. The coordinates are Washington Coordinate System, South Zone, NAD83/91 datum. Vertical datum is NAVD 1988 and is based on existing bench marks established by the U.S. Army Corps of Engineers. Survey data are included in Table 1.

\subsection{Well Development and Pump Installation}

Well 299-W19-41 was developed on September 30, 1998. A temporary, 2 hp submersible pump was used to remove approximately $1,075 \mathrm{gal}$ of formation water from the well at $7 \mathrm{gal} / \mathrm{min}$. The final turbidity was 2.01 NTU. 
Table 1. Survey Data for New Wells At Waste Management Area U

\begin{tabular}{|c|c|c|c|c|}
\hline Well Name & Easting (m) & Northing (m) & Elevation (m) & $2+4-4+20$ \\
\hline 299-W19-41 & $\begin{array}{l}566,896.532 \\
566,896.553\end{array}$ & $\begin{array}{l}135,004.5095 \\
135,004.796\end{array}$ & $\begin{array}{l}206.5308 \\
205.7812\end{array}$ & $\begin{array}{l}\text { Center of Casing } \\
\text { " } \mathrm{X} \text { " on Casing } \\
\text { Brass Cap }\end{array}$ \\
\hline 299-W19-42 & $\begin{array}{l}566,896.812 \\
566,896.7955\end{array}$ & $\begin{array}{l}135,122.901 \\
135,123,220\end{array}$ & $\begin{array}{l}206.2420 \\
205.5057\end{array}$ & $\begin{array}{l}\text { Center of Casing } \\
\text { "X" on Casing } \\
\text { Brass Cap }\end{array}$ \\
\hline
\end{tabular}

A dedicated Hydrostar sampling pump was installed in well 299-W19-41 on October 30, 1998. The sampling pump intake is at $241.50 \mathrm{ft}$ depth relative to the brass cap (see Table 1).

\subsection{Well 299-W19-42}

\subsection{Drilling}

Well 299-W19-42 was drilled using a cable tool rig with drive barrel from 0 to $140 \mathrm{ft}$ bgs and an air rotary rig from $140 \mathrm{ft}$ to a total depth of $265.2 \mathrm{ft}$ bgs during September 1998. Temporary 9-in.-outsidediameter, carbon steel casing was used from 0 to $135.7 \mathrm{ft}$ bgs and 8 5/8-in.-outside-diameter, carbon steel casing was used from 0 to $265.2 \mathrm{ft}$ bgs. About $300 \mathrm{gal}$ of water were added to the borehole at total depth to keep fine sediment out of the casing. Static water level was $219.56 \mathrm{ft}$ bgs on September 16, 1998.

Sediments encountered during drilling were predominantly sand and sandy gravel from the surface to about $89 \mathrm{ft}$ bgs; silty sands and silt from 89 to $138 \mathrm{ft} \mathrm{bgs;} \mathrm{caliche} \mathrm{from} 138$ to $141 \mathrm{ft}$ bgs; and silty, sandy gravel, sandy gravel and gravelly sand from 141 to $265^{\circ} \mathrm{ft}$ bgs. A clastic dike was identified by the geologist at $121 \mathrm{ft}$ bgs based on sediment texture.

Grab samples for particle size distribution were collected at 30 and $70 \mathrm{ft}$ bgs. Test results show that the 30 -ft sample is about 80 weight percent gravel and the deeper sample is dominantly sand with considerable silt and clay. Particle size data are included in Appendix B.

Grab samples also were collected at 5 - $\mathrm{ft}$ intervals from the surface to $140 \mathrm{ft}$ bgs for laboratory measurements of calcium carbonate and moisture contents, $\mathrm{pH}$, conductivity, cation exchange capacity, and extractable ions. Except for the nitrate concentration in the extracts from the 5-ft and 15-ft samples, the results of the analyses indicate that the sediments encountered during well installation are typical for natural Hanford Site sediments. The two anomolous nitrate values may represent a natural heterogeneity 
or a past near-surface spill. Two zone in the sediment profile have high carbonate content; 25 to $60 \mathrm{ft}$ bgs and 138.5 to $140 \mathrm{ft}$ bgs. The latter zone coincides with a caliche zone indicated on the geologists log. The results of all laboratory measurements of are in Appendix B.

Sediment samples also were collected from well 299-W19-42 for geologic description and archive at approximately 5-ft intervals from the surface to $141 \mathrm{ft}$ bgs and 10-ft intervals from 140 to $265 \mathrm{ft}$ bgs. The borehole and drill cuttings were monitored regularly for organic vapors and radionuclide contaminants. No contamination was noted.

The well was logged using high resolution, spectral gamma-ray instrumentation from the surface to $139 \mathrm{ft}$ on September 9, 1998, and from 118 to $262 \mathrm{ft}$ on September 13, 1998. The only man-made radionuclide detected was cesium-137 from the surface to $10 \mathrm{ft}$ bgs with a maximum activity of $8.7 \mathrm{pCi} / \mathrm{g}$ at $1.25 \mathrm{ft}$ bgs. The geophysical logs are in Appendix C.

\subsection{Well Completion}

The permanent casing and screen were installed in well 299-W19-42 in September 1998. A 4-in.inner-diameter, stainless steel, wire wrap (0.01 in. slot) screen was set from 220.28 to $255.37 \mathrm{ft}$ bgs. The permanent casing is 4-in.-inner-diameter stainless steel from $220.28 \mathrm{ft}$ bgs to $2.0 \mathrm{ft}$ above ground surface. Centralizers were placed at the top and bottom of the screen and every $40 \mathrm{ft}$ from the screen to the surface. The bottom of the screen has a 4-in. end cap.

The filter pack is $20-40$ mesh, silica sand and was placed from 265.1 to $210.2 \mathrm{ft}$ bgs. The annular seal is medium bentonite chips from 210.2 to $10.2 \mathrm{ft}$ bgs and Portland cement from $10.2 \mathrm{bgs}$ to the surface. A $4 \mathrm{ft}$ by $4 \mathrm{ft}$ by 6 in. concrete pad was placed around the well at the surface. A protective casing with locking cap, four protective steel posts, and a brass marker stamped with the well number were set into the concrete. The Well Construction Summary Report and the Well Summary Sheet (as-built) are included in Appendix A.

The vertical and horizontal coordinates of the well were surveyed in December 1998. The horizontal position of the well was determined by global positioning system observations referenced to horizontal control stations established by the U.S. Army Corps of Engineers. The coordinates are Washington Coordinate System, South Zone, NAD83/91 datum. Vertical datum is NAVD 1988 and is based on existing bench marks established by the U.S. Army Corps of Engineers. Survey data are included in Table 1.

\subsection{Well Development and Pump Installation}

Well 299-W19-42 was developed on September 22, 1998. A temporary, 2 hp submersible pump was used to remove about $1,125 \mathrm{gal}$ of formation water from the well at 6 to $7 \mathrm{gal} / \mathrm{min}$. 
A dedicated Hydrostar sampling pump was installed in well 299-W19-42 on October 30, 1998. The sampling pump intake is at $241.50 \mathrm{ft}$ depth relative to the brass cap (see Table 1).

\subsection{References}

Caggiano, J. A,. and S. M. Goodwin. 1991. Interim Status Groundwater Monitoring Plan for the SingleShell Tanks. WHC-SD-EN-AP-012, Rev. 1. Westinghouse Hanford Company, Richland, Washington.

Ecology - Washington State Department of Ecology, U.S. Environmental Protection Agency, and U.S. Department of Energy. 1996. Hanford Federal Facility Agreement and Consent Order. Document No. 89-110, Rev. 4 (The Tri-Party Agreement), Ecology, Olympia, Washington.

RCRA - Resource Conservation and Recovery Act. 1976. Public Law 94-580, as amended, 90 Stat. 2795, 42 USC 6901 et seq.

WAC 173-160, Washington Administrative Code. Minimum Standards for Construction and Maintenance of Wells. Olympia, Washington.

WAC 173-303, Washington Administrative Code. Dangerous Waste Regulations. Olympia, Washington. 


\section{Appendix A}

Well Construction and Completion Documentation 


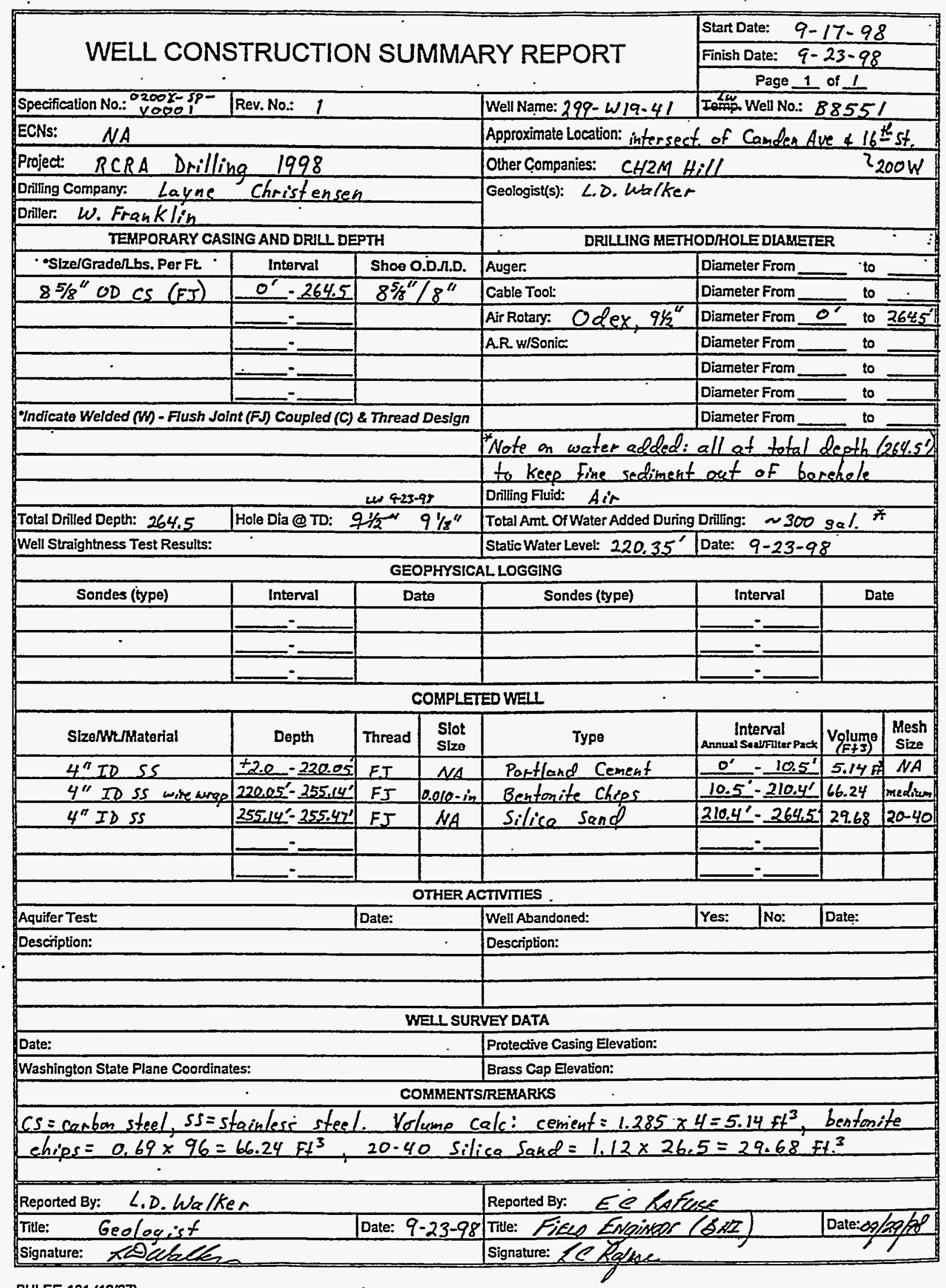

BHI-EE-181 (12/97) 




BHI-EE-189 (12/97) 
WELL SUMMARY SHEET

Page $\frac{4^{2} \text { of } 2^{\circ}}{9 \cdot 1}$

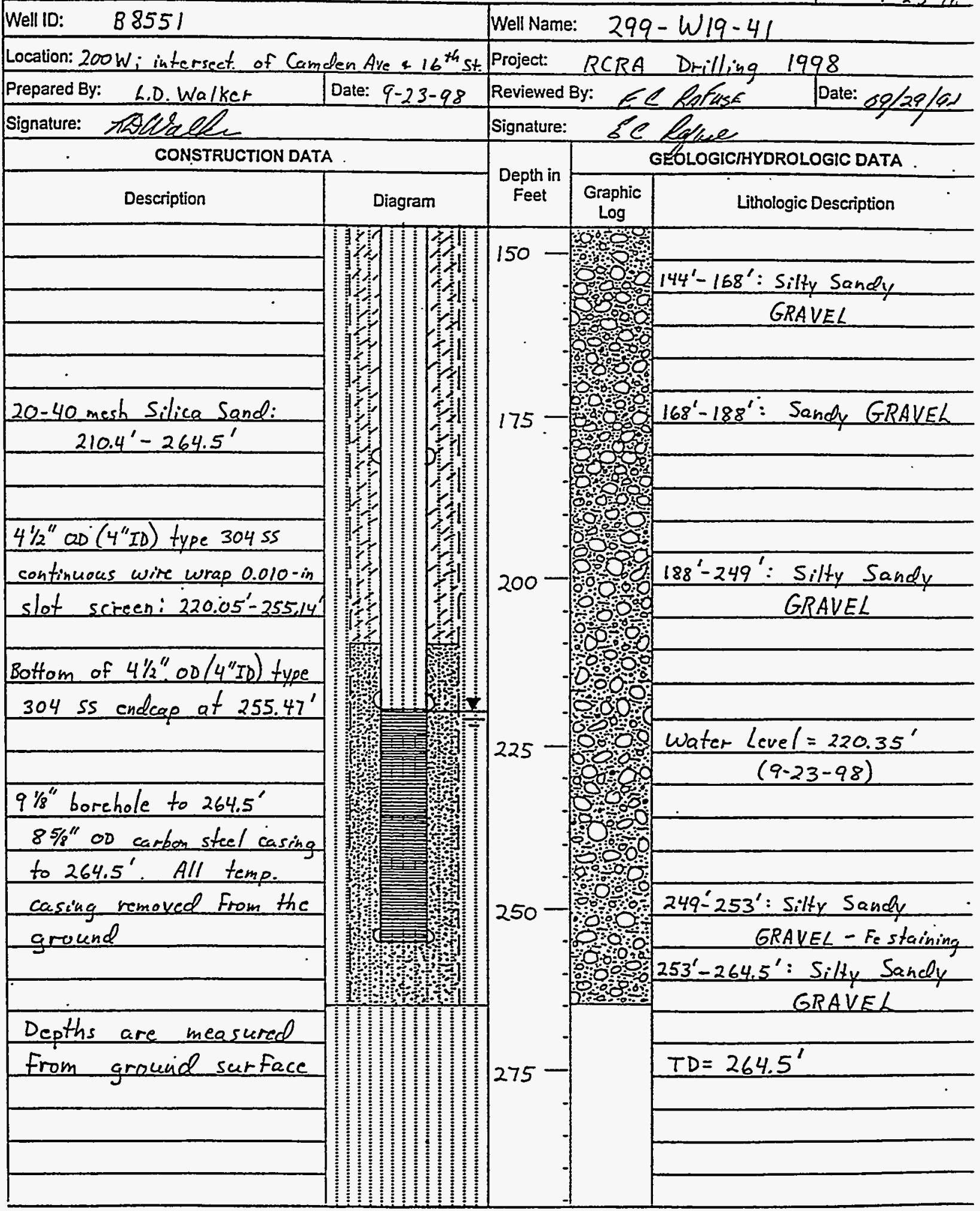




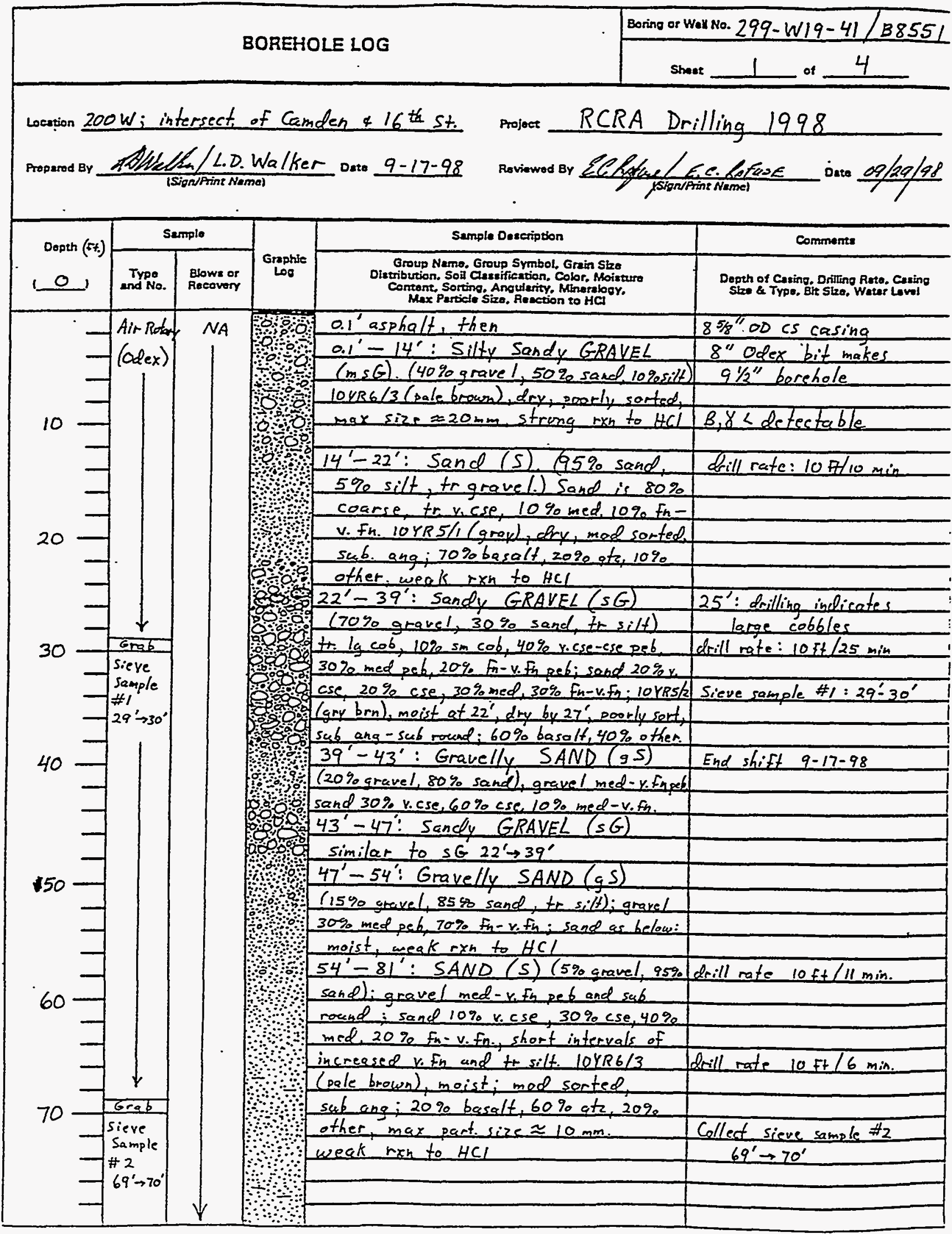




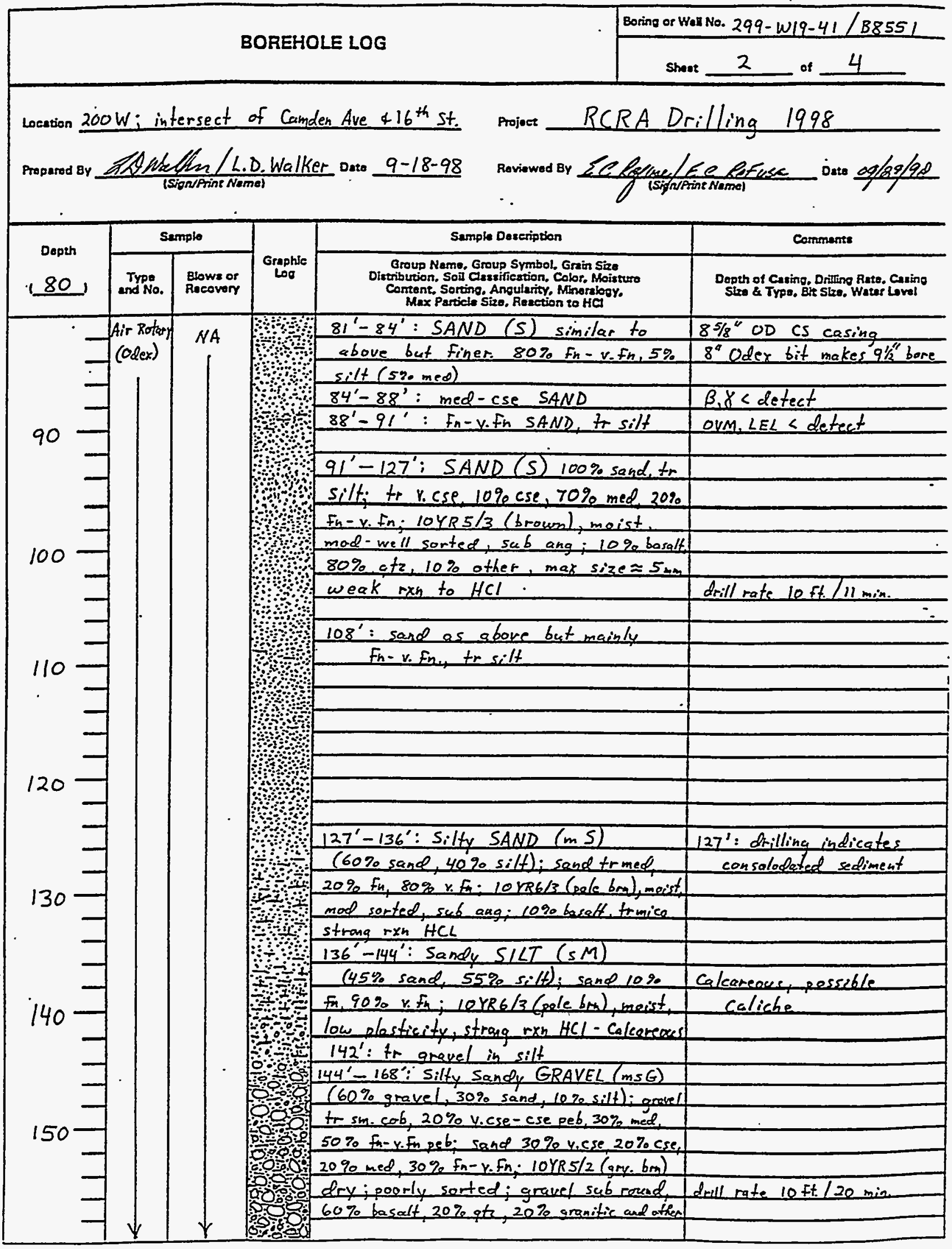




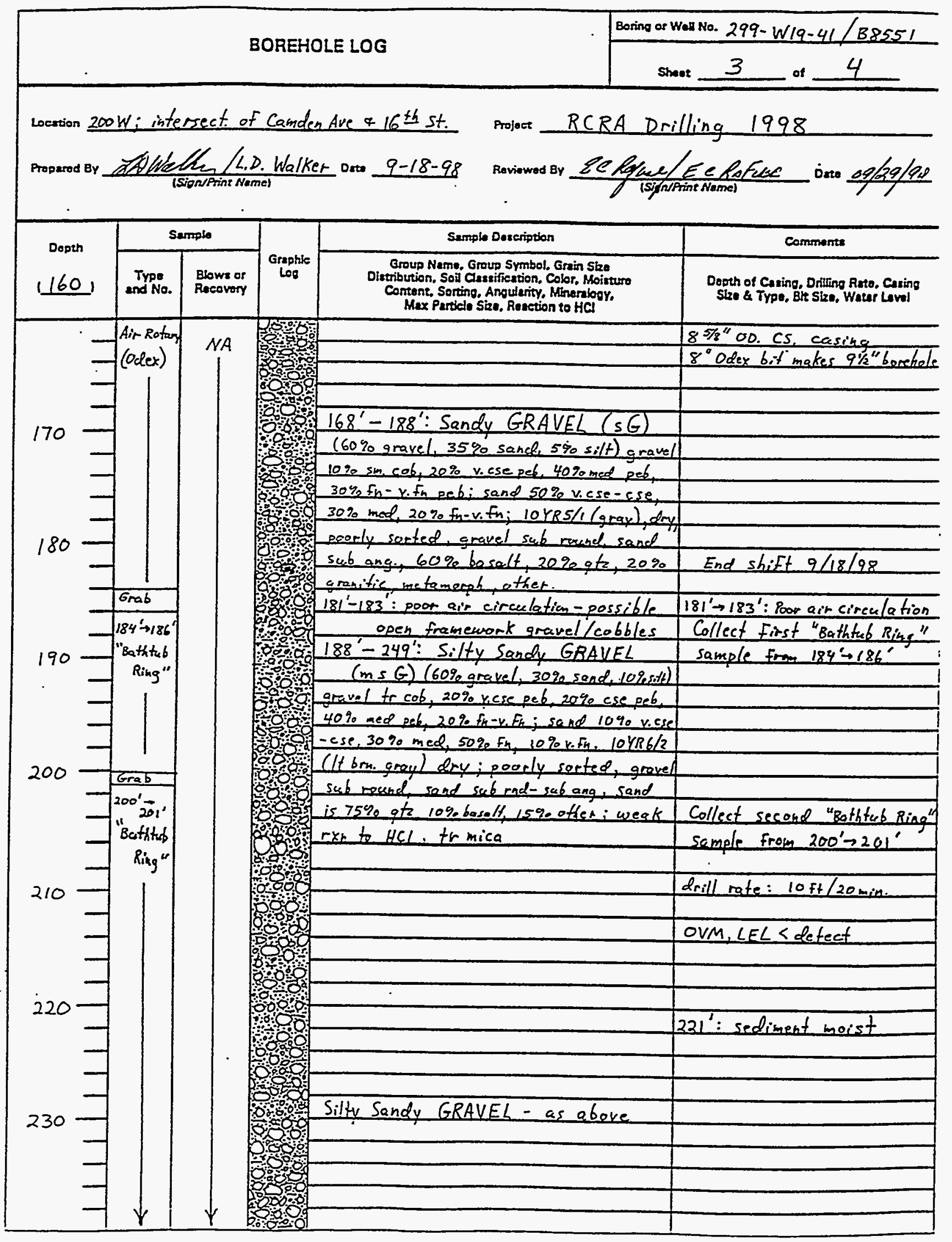




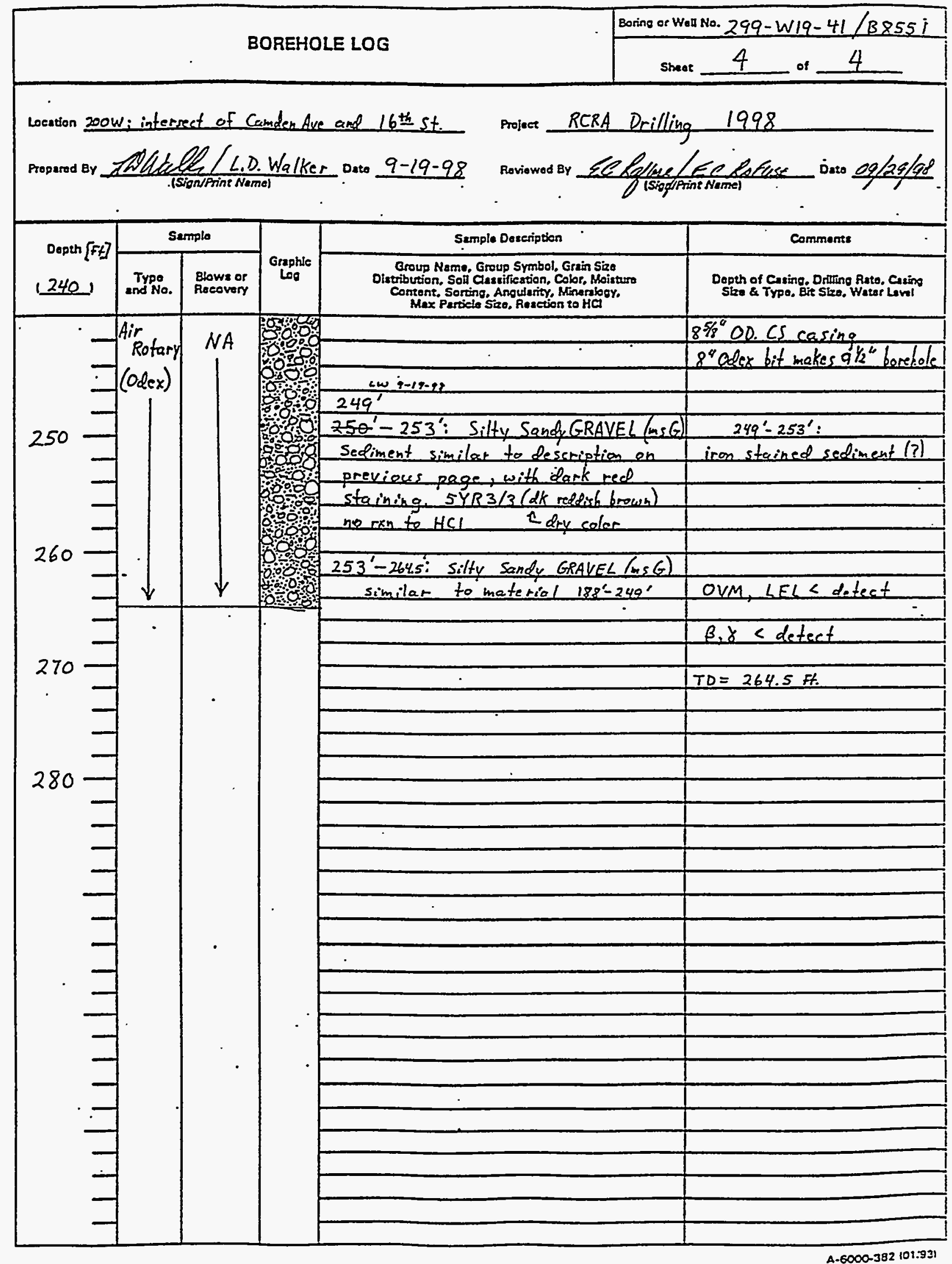

A. 7 


\section{WELL CONSTFUCTION SUMMARY REPOR :}

\begin{tabular}{|l|}
\hline Start Date: $\quad 8 / 31 / 98$ \\
\hline Finish Date: $9-16-98$ \\
\hline Page 1 of 1 \\
\hline
\end{tabular}

Well Name: $299-w 19-42$ Fon. Well No: 38553 Approximate Location: $55^{\prime}$ Egs fof $244-U$ Tankfom, 2004 Other Companies: $\mathrm{CH} 2 \mathrm{M}$ Hill Geologist(s): DCukekes

Drilling Company: Layne Christensen

Driller. M. Wraspir $L \cdot W$. Franklín TEMPORARY CASING AND DRLL DEPTH

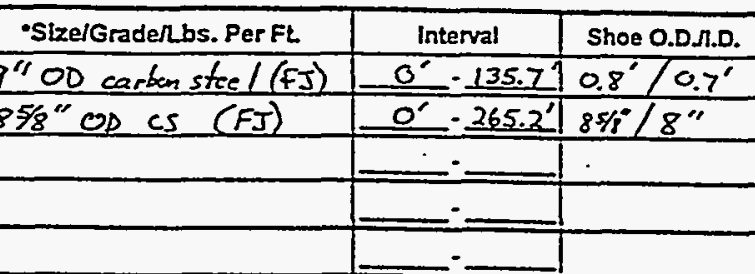
Indicate Welded (M) - Flush Joint (F) Coupled (C) \& Thread Design

Note on water added: all. at total depth to keep fine sediment out of casing Drilling Fluid: Air

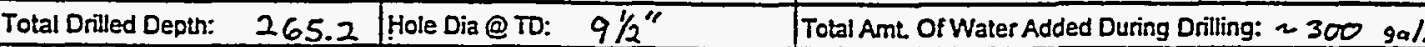

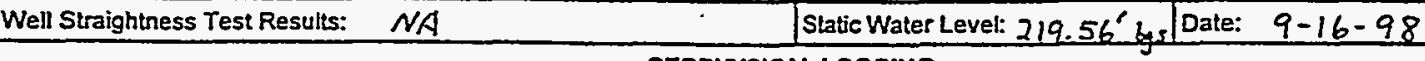

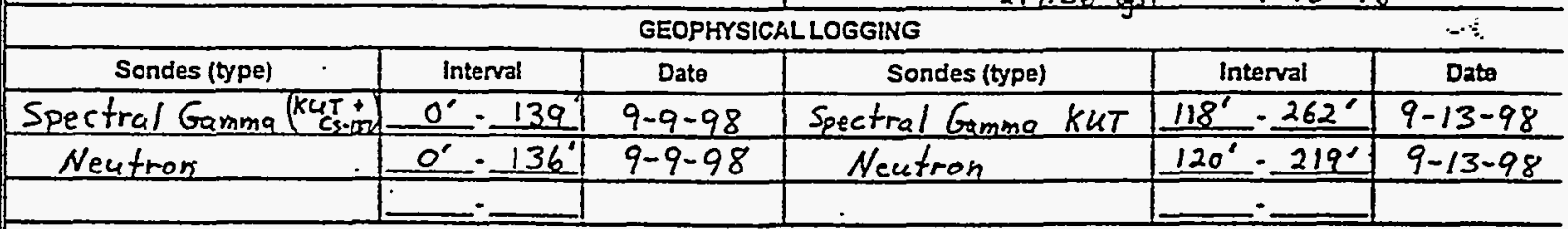
COMPLETED WEL

$\angle D$ walker DRILUNG METHODHOLE DLAMEIERE: :

Auger. $\quad$ Diameter From _ $\quad$ to $\div$

Cable Tool: Drive Garre/ Diameter From $0^{\circ}$ to $140^{\prime}$ Air Rotary. Odex; $91^{\prime \prime}$ Diameter From $0^{\prime}$ to 265.2 A.R. w/Sonic:

Diameter From 10 to
Diameter From to Diameter From to to Diameter From to

\begin{tabular}{|l|l|l}
\hline & \\
\hline Total Drilled Depin: 265.2 & Hole Dia @ TD: 9/2" \\
\hline
\end{tabular}

Sizen/Material

$4^{\prime \prime}$ TD 55

$4 "$ ID SS wire wrap

4" ID S5

\begin{tabular}{|c|c|c|}
\hline Depth & Thread & $\begin{array}{c}\text { Slot } \\
\text { Sizo }\end{array}$ \\
\hline$+2.0-220.28$ & FI & NA \\
\hline $320.28^{\circ}-255.37^{\prime}$ & GJ & $0.010-$ in \\
\hline $255.37^{\circ}-255.70^{\prime}$ & FJ & NA \\
\hline & & \\
\hline & & \\
\hline
\end{tabular}

OTHEFACTIVTIES

\begin{tabular}{|l|l|}
\hline Aquifer.Test: & Date: \\
\hline Description: & \\
\hline
\end{tabular}

$$
\text { Date: }
$$

WEILSURVEY.DATA

Well Abandoned:

Description:

Type
Portland Cement
Bentanite Chips
Silica Sand

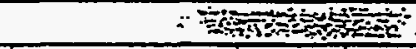

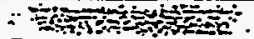

\begin{tabular}{|c|c|c|}
\hline $\begin{array}{l}\text { Interval } \\
\text { Annual Sedfruler Pask }\end{array}$ & Volumo & $\begin{array}{l}\text { Mlesh } \\
\text { Size }\end{array}$ \\
\hline $0^{\prime}-10.2^{\prime}$ & 30.84 & $N A$ \\
\hline $10.2^{\prime}-210.2$ & 75.21 & mediun \\
\hline $210.2^{\prime}-265.1^{\prime}$ & 29.68 & $20-4 c$ \\
\hline & & \\
\hline$=$ & & \\
\hline
\end{tabular}

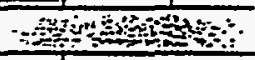

Protective Casing Elevation:

\section{Washington State Plane Coordinates:}

Brass Cap Elevation:

COMIEENTSIREMARKS

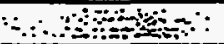

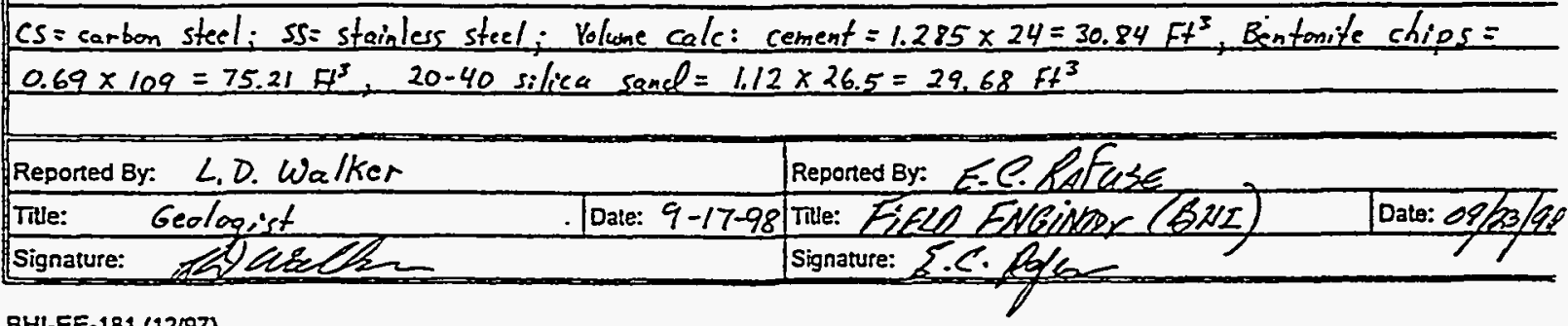




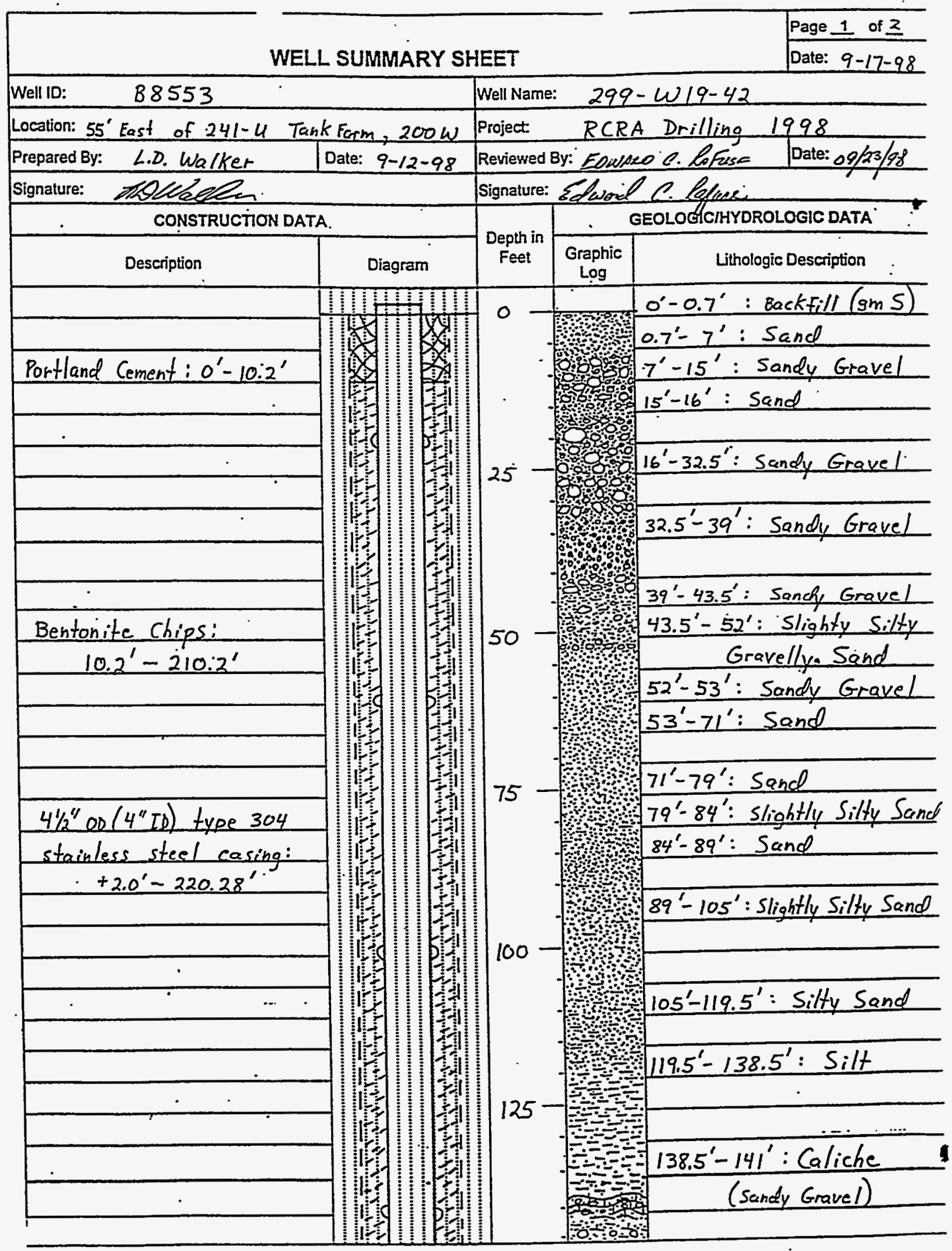

BHI-EE-189 (12/97) 
WELL SUMMARY SHEET

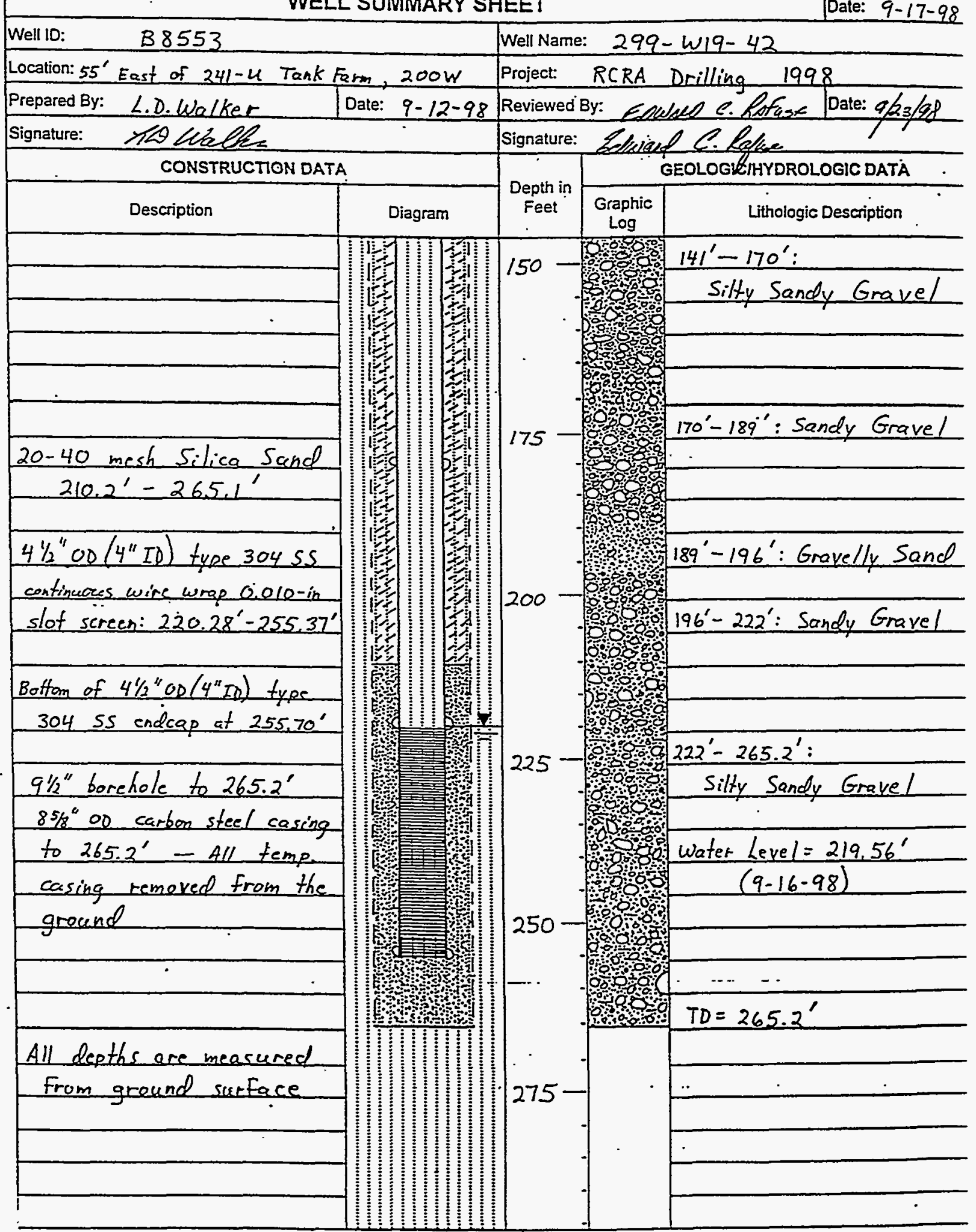




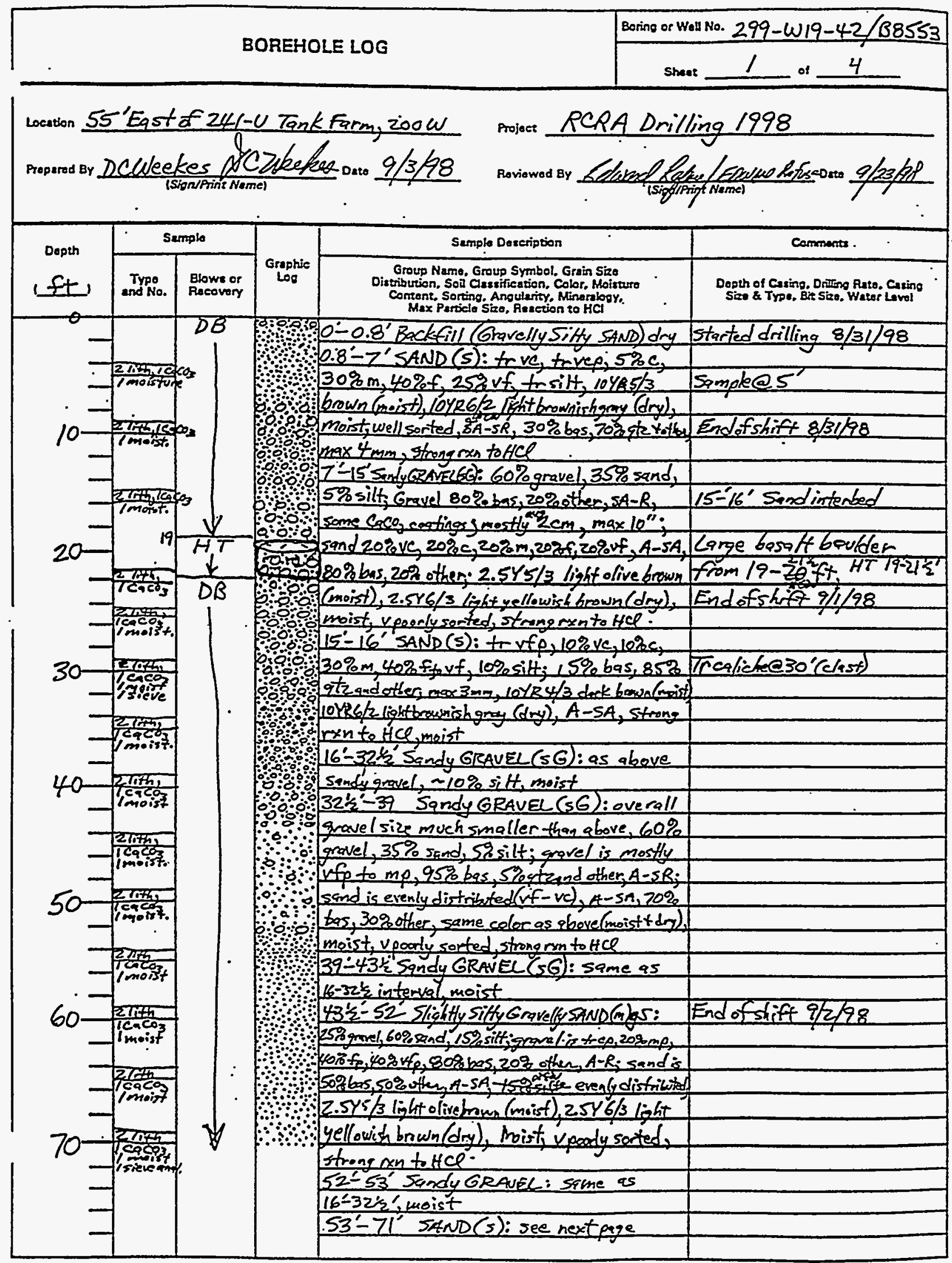

A.6000-382 101/931 


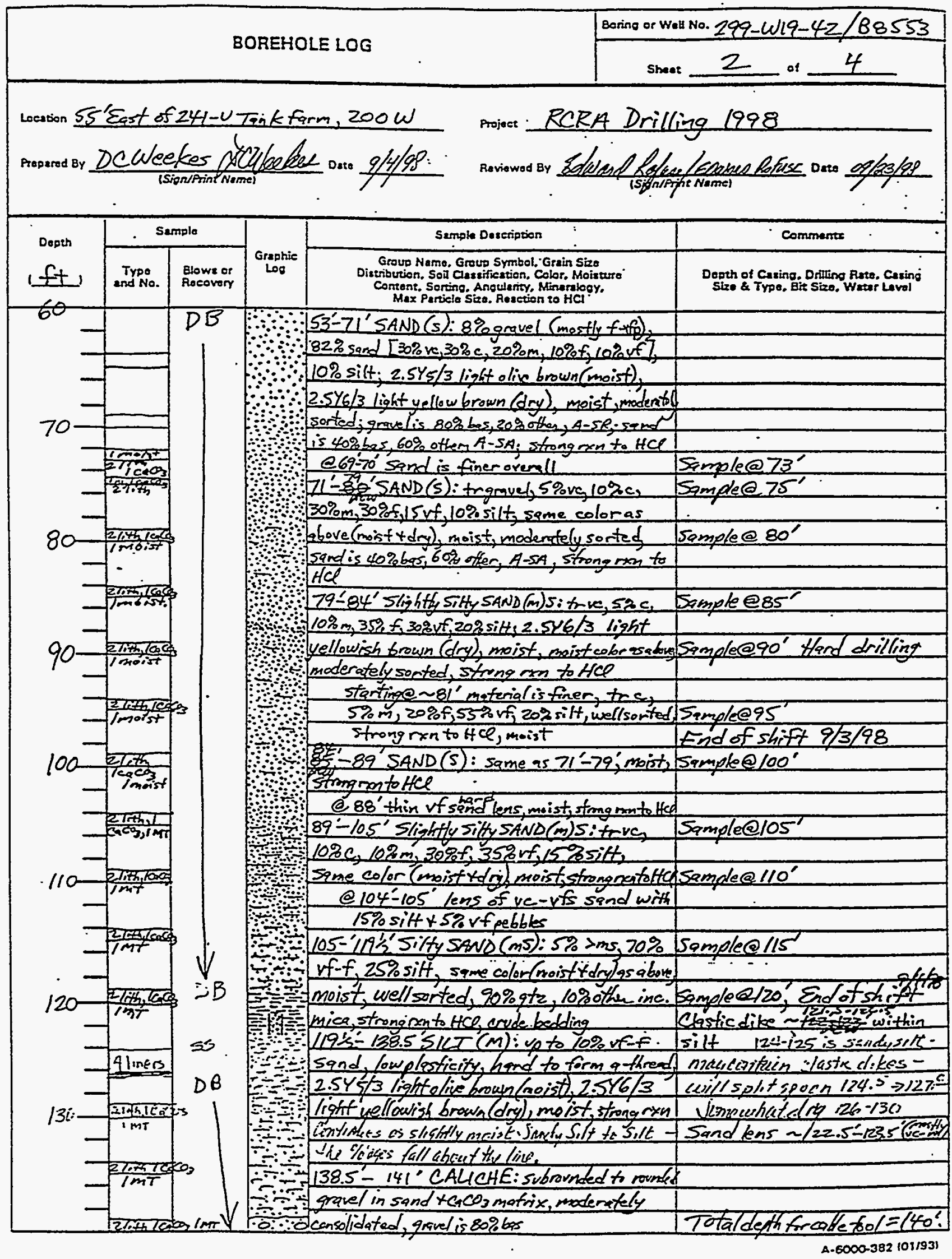









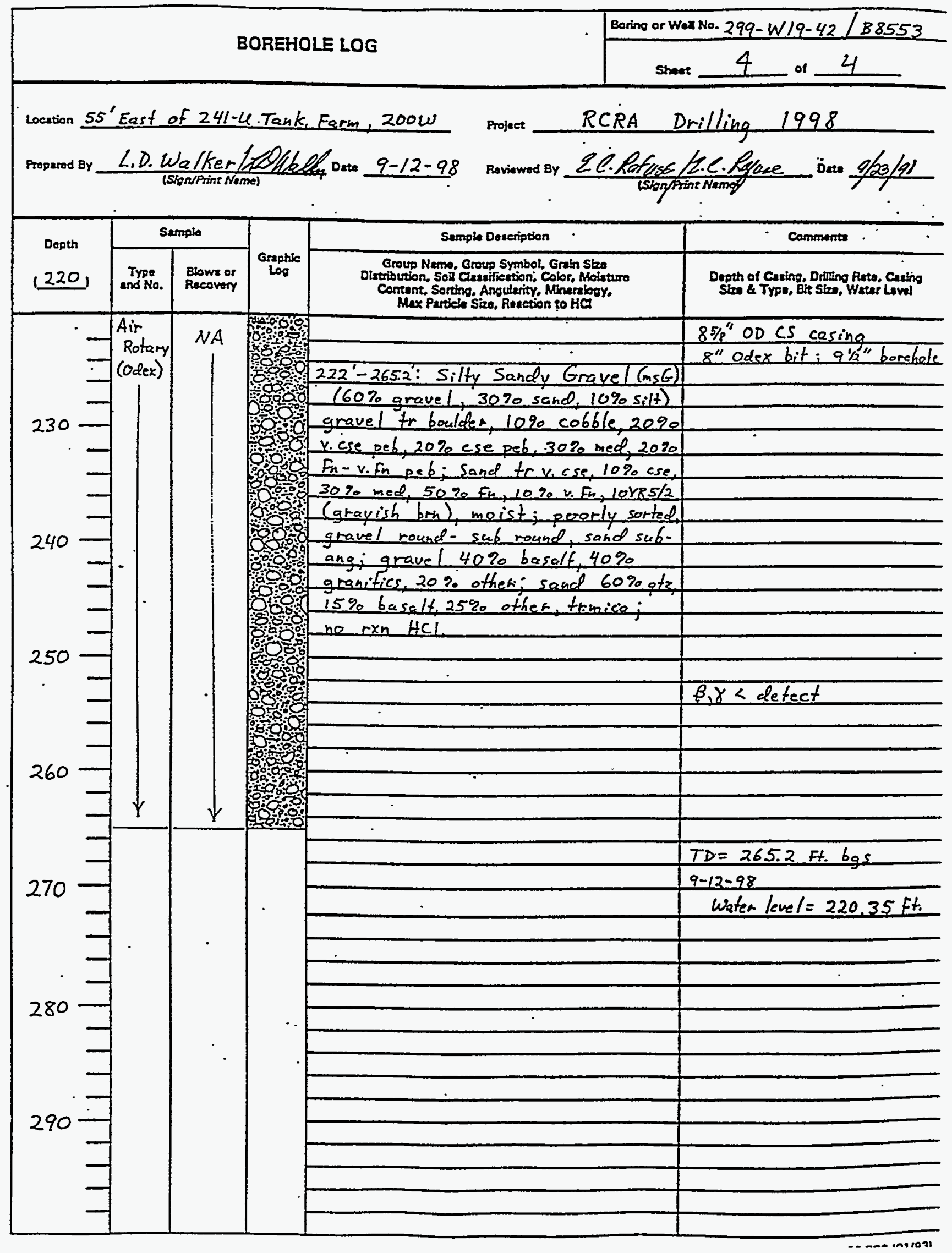




\section{Appendix B}

\section{Physical and Chemical Properties Data}




\section{Appendix B}

\section{Physical and Chemical Properties Data}

This Appendix includes the results of laboratory testing for particle size distribution, moisture content, calcium carbonate content, $\mathrm{pH}$, electrical conductivity, cation exchange capacity, and water extractable ions.

Moisture content was measured as weight loss after drying an aliquot of the bulk sample at $105^{\circ} \mathrm{C}$ for 24 h or until weight was constant for two consecutive measurements.

Calcium carbonate content was determined as the gravimetric equivalent of measured total carbon from an air-dried aliquot of the $<2 \mathrm{~mm}$ fraction. The sample was combusted in a total carbon analyzer at $975^{\circ} \mathrm{C}$ and the weight of evolved carbon dioxide was determined and converted to calcium carbonate equivalent. Reagent grade calcium carbonate was used as a standard. Instrument precision was $\pm 3 w t \%$ based on replicate measurements of reagent grade calcium carbonate.

Exchangeable cations were determined by inductively coupled plasma analysis (ICP) after exchange with an ammonium acetate solution. Twenty grams of air dried sediment was mixed with $50 \mathrm{~mL}$ of $1 \mathrm{M}$ ammonium acetate for $16 \mathrm{~h}$. Electrical conductivity, $\mathrm{pH}$, and major cations and anions were determined from a 1:1 water:sediment extract. The concentrations of major cations were measured with ICP, anions were determined by ion chromatography, and alkalinity was measured by titration. Electrical conductivity and $\mathrm{pH}$ were determined from unfiltered aliquots and cations and anions from aliquots of solution filtered through $0.45 \mu \mathrm{m}$ membranes.

Particle size analysis was done using standard sieve techniques. Samples were oven dried at $105^{\circ} \mathrm{C}$ for $24 \mathrm{~h}$ (or until weight was constant for two consecutive measurements) prior to analysis. 
Table B.1. Particle Size Data for Samples from Wells 299-W19-41 and 299-W19-42

\begin{tabular}{|c|c|c|c|}
\hline $\begin{array}{c}\text { Particle } \\
\text { Size (mm) }\end{array}$ & Sieve & $\begin{array}{l}\text { Weight of } \\
\text { Dry } \\
\text { Sample (g) }\end{array}$ & $\begin{array}{l}\text { Weight } \\
\text { Percent }\end{array}$ \\
\hline \multicolumn{4}{|c|}{ 299-W19-41-Depth 29 to $30 \mathrm{ft}$} \\
\hline 2 & 10 & 561 & 82.1 \\
\hline 0.88 & 20 & 67.9 & 9.9 \\
\hline 0.425 & 40 & 23.41 & 3.4 \\
\hline 0.25 & 60 & 5.61 & 0.8 \\
\hline 0.106 & 140 & 5.16 & 0.8 \\
\hline 0.075 & 200 & 2.1 & 0.3 \\
\hline \multirow[t]{2}{*}{$<0.075$} & Pan & 18.11 & 2.7 \\
\hline & Total & 683.29 & 100.0 \\
\hline \multicolumn{4}{|c|}{ 299-W19-41-Depth 69 to $70 \mathrm{ft}$} \\
\hline 2 & 10 & 1.8 & 0.9 \\
\hline 0.88 & 20 & 27.54 & 14.4 \\
\hline 0.425 & 40 & 77.59 & 40.5 \\
\hline 0.25 & 60 & 55.9 & 29.2 \\
\hline 0.106 & 140 & 20.39 & 10.6 \\
\hline 0.075 & 200 & 2.69 & 1.4 \\
\hline \multirow[t]{2}{*}{$<0.075$} & Pan & 5.55 & 2.9 \\
\hline & Total & 191.46 & 100.0 \\
\hline
\end{tabular}

\begin{tabular}{|c|c|c|c|}
\hline $\begin{array}{l}\text { Particle } \\
\text { Size (mm) }\end{array}$ & $\begin{array}{l}-+4 \\
\text { Sieve }\end{array}$ & $\begin{array}{l}\text { Weight of } \\
\text { Dry Sample } \\
\text { (g) }\end{array}$ & $\begin{array}{l}\text { Weight } \\
\text { Percent }\end{array}$ \\
\hline \multicolumn{4}{|c|}{ 299-W19-42 Depth $30 \mathrm{ft}$} \\
\hline 2 & 10 & 783 & 80.0 \\
\hline 0.88 & 20 & 57.55 & 5.9 \\
\hline 0.425 & 40 & 51.97 & 5.3 \\
\hline 0.25 & 60 & 31.12 & 3.2 \\
\hline 0.106 & 140 & 29.07 & 3.0 \\
\hline 0.075 & 200 & 6.95 & 0.7 \\
\hline \multirow[t]{2}{*}{$<0.075$} & Pan & 19.09 & 2.0 \\
\hline & Total & 978.75 & 100.0 \\
\hline \multicolumn{4}{|c|}{ 299-W19-42 Depth 70 ft } \\
\hline 2 & 10 & 2.4 & 1.2 \\
\hline 0.88 & 20 & 20.72 & 10.7 \\
\hline 0.425 & 40 & 66.77 & 34.5 \\
\hline 0.25 & 60 & 44.4 & 23.0 \\
\hline 0.106 & 140 & 29.05 & 15.0 \\
\hline 0.075 & 200 & 7.88 & 4.1 \\
\hline \multirow[t]{2}{*}{$<0.075$} & Pan & 22.18 & 11.5 \\
\hline & Total & 193.4 & 100.0 \\
\hline
\end{tabular}


Table B.2. Moisture Content, $\mathrm{pH}$, and Electrical Conductivity for Samples from Well 299-W19-42

\begin{tabular}{|c|c|c|c|c|}
\hline $\begin{array}{l}\text { Sample Depth } \\
\text { (ft) }\end{array}$ & $\begin{array}{l}\text { Moisture } \\
\text { Content (wt\%) }\end{array}$ & $\mathrm{pH}$ & $\begin{array}{l}\text { Condectrical } \\
\text { Conctivy }(\mathrm{\mu S} / \mathrm{cm})\end{array}$ & Temperature $(\mathrm{C})$ \\
\hline 5 & 8.2 & 8.42 & 141 & 16.3 \\
\hline 10 & 8.8 & 8.86 & 114 & 16.2 \\
\hline 15 & 12.2 & 8.72 & 198 & 16.4 \\
\hline 25 & 5.9 & 8.83 & 143 & 16.2 \\
\hline 30 & 4.0 & 8.82 & 110 & 15.9 \\
\hline 35 & 3.6 & 8.62 & 129 & 15.1 \\
\hline 40 & 3.8 & 8.89 & 117 & 16.3 \\
\hline 45 & 4.0 & 8.55 & 125 & 15.6 \\
\hline 50 & 9.3 & 8.52 & 115 & 15.6 \\
\hline 55 & 3.9 & 8.62 & 117 & 16.0 \\
\hline 60 & 6.7 & 8.5 & 148 & 15.2 \\
\hline 65 & 3.0 & 8.51 & 147 & 15.9 \\
\hline 70 & 3.4 & 8.58 & 154 & 15.4 \\
\hline 73 & 7.2 & 8.58 & 138 & 15.8 \\
\hline 75 & 2.9 & 8.56 & 140 & 16.2 \\
\hline 80 & 6.0 & 8.48 & 175 & 16.2 \\
\hline 85 & 3.3 & 8.58 & 136 & 15.7 \\
\hline 90 & 6.4 & 8.3 & 154 & 14.0 \\
\hline 95 & 6.0 & 8.29 & 136 & 16.2 \\
\hline 100 & 5.6 & 8.45 & 143 & 15.7 \\
\hline 105 & 7.3 & 8.45 & 132 & 15.5 \\
\hline 110 & 6.6 & 8.47 & 131 & 15.6 \\
\hline 115 & 4.4 & 8.46 & 131 & 15.6 \\
\hline 120 & 14.5 & 8.32 & 158 & 15.6 \\
\hline 130 & 12.7 & NA & NA & NA \\
\hline 135 & 15.2 & 8.32 & 147 & 15.6 \\
\hline 138.5 & 22.0 & 7.83 & 201 & 17.2 \\
\hline 140 & 20.4 & 7.88 & 203 & 17.2 \\
\hline
\end{tabular}


Table B.3. Major Cations, Major Anions, and Alkalinity for Samples from Well 299-W19-42

\begin{tabular}{|c|c|c|c|c|c|c|c|c|c|}
\hline \multirow{2}{*}{$\begin{array}{l}\text { Depth } \\
\text { (ft) }\end{array}$} & \multicolumn{6}{|c|}{ Cations (mg/L) } & \multirow{2}{*}{$\begin{array}{l}\text { Total } \\
\text { Cations } \\
\text { (meq/L) }\end{array}$} & \multirow{2}{*}{$\begin{array}{l}\text { Monovalent } \\
\text { Cations } \\
(\%)\end{array}$} & \multirow{2}{*}{$\begin{array}{c}\text { Divalent } \\
\text { Cations } \\
(\%)\end{array}$} \\
\hline & $\mathbf{B a}$ & $\mathrm{Ca}$ & $\mathbf{K}$ & $\mathbf{M g}$ & $\mathrm{Na}$ & $\mathbf{S r}$ & & & \\
\hline 5 & 0.00 & 32.76 & 6.94 & 3.14 & 5.66 & 0.07 & 2.32 & 18.28 & 81.72 \\
\hline 10 & 0.05 & 12.45 & 10.40 & 5.65 & 10.83 & 0.07 & 1.82 & 40.39 & 59.61 \\
\hline 15 & 0.00 & 10.14 & 9.37 & 1.84 & 44.88 & 0.04 & 2.85 & 76.90 & 23.10 \\
\hline 25 & 0.01 & 8.91 & 10.58 & 1.38 & 16.14 & 0.05 & 1.53 & 63.46 & 36.54 \\
\hline 30 & 0.09 & 10.22 & 7.23 & 1.92 & 17.82 & 0.06 & 1.63 & 58.87 & 41.13 \\
\hline 35 & 0.20 & 11.27 & 7.57 & 3.05 & 12.68 & 0.07 & 1.56 & 47.67 & 52.33 \\
\hline 40 & 0.11 & 9.80 & 8.49 & 2.37 & 10.83 & 0.06 & 1.38 & 50.02 & 49.98 \\
\hline 45 & 0.11 & 10.83 & 4.16 & 3.24 & 11.94 & 0.08 & 1.44 & 43.57 & 56.43 \\
\hline 50 & 0.17 & 10.59 & 3.42 & 3.61 & 7.58 & 0.07 & 1.25 & 33.49 & 66.51 \\
\hline 55 & 0.09 & 9.59 & 10.19 & 2.84 & 11.30 & 0.07 & 1.47 & 51.26 & 48.74 \\
\hline 60 & 0.18 & 11.48 & 6.67 & 3.67 & 9.57 & 0.09 & 1.47 & 40.01 & 59.99 \\
\hline 65 & 0.13 & 12.58 & 2.22 & 4.07 & 6.18 & 0.09 & 1.29 & 25.18 & 74.82 \\
\hline 70 & 0.14 & 12.82 & 4.16 & 4.08 & 10.14 & 0.09 & 1.53 & 35.85 & 64.15 \\
\hline 73 & 0.10 & 10.63 & 1.75 & 3.22 & 13.38 & 0.08 & 1.43 & 43.95 & 56.05 \\
\hline 75 & 0.16 & 9.59 & 4.14 & 3.08 & 11.85 & 0.08 & 1.36 & 45.77 & 54.23 \\
\hline 80 & 0.34 & 13.39 & 0.00 & 4.05 & 13.85 & 0.10 & 1.61 & 37.38 & 62.62 \\
\hline 85 & 0.16 & 10.58 & 4.39 & 3.50 & 10.85 & 0.08 & 1.40 & 41.62 & 58.38 \\
\hline 90 & 0.24 & 11.85 & 6.00 & 2.83 & 11.34 & 0.07 & 1.48 & 43.82 & 56.18 \\
\hline 95 & 0.11 & 11.46 & 4.94 & 2.54 & 7.98 & 0.08 & 1.26 & 37.66 & 62.34 \\
\hline 100 & 0.24 & 11.62 & 1.82 & 2.49 & 12.37 & 0.07 & 1.37 & 42.53 & 57.47 \\
\hline 105 & 0.13 & 10.01 & 0.00 & 2.12 & 8.40 & 0.05 & 1.04 & 35.03 & 64.97 \\
\hline 110 & 0.10 & 11.76 & 0.00 & 2.50 & 10.54 & 0.07 & 1.25 & 36.55 & 63.45 \\
\hline 115 & 0.02 & 11.83 & 0.00 & 2.76 & 13.75 & 0.06 & 1.42 & 42.21 & 57.79 \\
\hline 120 & 0.03 & 13.00 & 0.00 & 2.88 & 16.82 & 0.06 & 1.62 & 45.18 & 54.82 \\
\hline 130 & 0.08 & 11.98 & 0.00 & 3.05 & 13.95 & 0.05 & 1.46 & 41.63 & 58.37 \\
\hline 135 & 0.17 & 11.82 & 0.00 & 3.75 & 16.59 & 0.06 & 1.62 & 44.43 & 55.57 \\
\hline 138.5 & 0.17 & 14.88 & 0.00 & 6.27 & 16.35 & 0.10 & 1.97 & 36.02 & 63.98 \\
\hline 140 & 0.26 & 15.31 & 0.00 & 6.13 & 8.69 & 0.10 & 1.65 & 22.88 & 77.12 \\
\hline
\end{tabular}


Table B.3. (contd)

\begin{tabular}{|c|c|c|c|c|c|c|c|}
\hline \multirow[b]{2}{*}{ Depth (ft) } & \multicolumn{5}{|c|}{ Anions (mg/L) } & \multirow{2}{*}{$\begin{array}{l}\text { Total } \\
\text { Anions } \\
\text { (meq/L) }\end{array}$} & \multirow{2}{*}{ Electrical Balance (\%) } \\
\hline & $\begin{array}{l}\text { Alkalinity } \\
\text { as } \mathrm{CaCO}_{3}\end{array}$ & $\mathbf{F}$ & $\mathrm{Cl}$ & $\mathrm{NO}_{3}$ & $\mathbf{S O}_{4}$ & & \\
\hline 5 & 108.60 & 0.54 & 3.07 & 6.69 & 2.69 & 2.45 & -5.56 \\
\hline 10 & 55.55 & 0.54 & 0.89 & $<0.06$ & 2.88 & 1.22 & 39.40 \\
\hline 15 & 89.32 & 1.80 & 2.84 & 4.65 & 10.32 & 2.25 & 23.49 \\
\hline 25 & 60.00 & 0.68 & 2.07 & 1.39 & 8.90 & 1.50 & 2.02 \\
\hline 30 & 52.83 & 0.66 & 2.06 & $<0.06$ & 9.77 & 1.35 & 18.64 \\
\hline 35 & 55.03 & 0.52 & 2.52 & 0.98 & 9.37 & 1.41 & 10.29 \\
\hline 40 & 45.91 & 0.52 & 2.14 & $<0.06$ & 10.35 & 1.22 & 11.87 \\
\hline 45 & 50.20 & 0.49 & 1.90 & 1.99 & 10.37 & 1.33 & 7.65 \\
\hline 50 & 51.36 & 0.40 & 2.63 & 2.20 & 8.21 & 1.33 . & -6.40 \\
\hline 55 & 51.04 & 0.43 & 1.92 & 1.13 & 7.63 & 1.27 & 14.06 \\
\hline 60 & 53.04 & 0.60 & 2.72 & 0.94 & 20.41 & 1.61 & -9.25 \\
\hline 65 & 46.64 & 0.31 & 1.68 & 1.06 & 20.69 & 1.44 & -11.17 \\
\hline 70 & 52.41 & 0.54 & 2.44 & $<0.06$ & 16.17 & 1.48 & 2.95 \\
\hline 73 & 36.36 & 0.49 & 2.22 & $<0.06$ & 9.90 & 1.02 & 33.01 \\
\hline 75 & 50.60 & 0.43 & 1.38 & $<0.06$ & 7.12 & 1.22 & 10.47 \\
\hline 80 & 53.04 & 0.59 & 1.65 & $<0.06$ & 28.81 & 1.74 & -7.60 \\
\hline 85 & 55.03 & 0.42 & 1.37 & $<0.06$ & 7.33 & 1.31 & 6.63 \\
\hline 90 & 67.51 & 0.58 & 1.44 & $<0.06$ & 9.96 & 1.63 & -9.83 \\
\hline 95 & 52.83 & 0.49 & 0.79 & $<0.06$ & 7.40 & 1.26 & -0.11 \\
\hline 100 & 54.10 & 0.52 & 1.33 & $<0.06$ & 8.63 & 1.33 & 3.58 \\
\hline 105 & 37.09 & 0.39 & 0.76 & $<0.06$ & 5.81 & 0.90 & 14.14 \\
\hline 110 & 51.36 & 0.45 & 0.69 & $<0.06$ & 10.42 & 1.29 & -2.58 \\
\hline 115 & 54.51 & 0.50 & 0.80 & 0.16 & 11.88 & 1.39 & 2.04 \\
\hline 120 & 55.93 & 0.84 & 1.43 & $<0.06$ & 14.18 & 1.50 & 7.73 \\
\hline 130 & 70.23 & 0.63 & 0.70 & $<0.06$ & 9.69 & 1.66 & -12.92 \\
\hline 135 & 67.96 & 0.54 & 1.12 & $<0.06$ & 10.15 & 1.63 & -0.39 \\
\hline 138.5 & 69.64 & 0.92 & 0.61 & 0.32 & 14.57 & 1.77 & 11.06 \\
\hline 140 & 72.32 & $0: 90$ & 0.63 & 0.13 & 11.99 & 1.76 & -6.46 \\
\hline
\end{tabular}


Table B.4. Cation Exchange Capacity and $\mathrm{CaCO}_{3}$ Content for Samples from Well 299-W19-42

\begin{tabular}{|c|c|c|c|}
\hline Depth (ft) & $\begin{array}{c}\text { CEC } \\
\text { (meq/100g) }\end{array}$ & $\begin{array}{c}\text { Divalent } \\
\text { Cations } \\
(\%)\end{array}$ & $\begin{array}{l}\mathrm{CaCO}_{3} \\
(w t \%)\end{array}$ \\
\hline 5 & 7.38 & 98.26 & 3.48 \\
\hline 10 & \multirow[t]{2}{*}{8.21} & \multirow[t]{2}{*}{95.94} & \multirow[t]{2}{*}{3.43} \\
\hline 15 & & & \\
\hline 25 & \multirow[t]{3}{*}{8.04} & \multirow[t]{3}{*}{94.43} & \multirow{3}{*}{26.06} \\
\hline 30 & & & \\
\hline 35 & & & \\
\hline 40 & \multirow[t]{3}{*}{6.11} & \multirow[t]{3}{*}{94.90} & \multirow[t]{3}{*}{15.84} \\
\hline 45 & & & \\
\hline 50 & & & \\
\hline 55 & 4.50 & 96.87 & 12.42 \\
\hline 60 & \multirow[t]{5}{*}{4.92} & \multirow[t]{5}{*}{94.51} & \multirow[t]{5}{*}{8.25} \\
\hline 65 & & & \\
\hline 70 & & & \\
\hline 73 & & & \\
\hline 75 & & & \\
\hline 80 & 5.90 & 93.77 & 1.84 \\
\hline 85 & \multirow[t]{2}{*}{5.38} & \multirow[t]{2}{*}{94.26} & \multirow[t]{2}{*}{2.91} \\
\hline 90 & & & \\
\hline 95 & \multirow[t]{5}{*}{5.72} & \multirow[t]{5}{*}{95.03} & \multirow[t]{5}{*}{2.04} \\
\hline 100 & & & \\
\hline 105 & & & \\
\hline 110 & & & \\
\hline 115 & & & \\
\hline 120 & 8.81 & 92.90 & 3.18 \\
\hline 130 & \multirow[t]{2}{*}{7.63} & \multirow[t]{2}{*}{95.19} & \multirow[t]{2}{*}{2.97} \\
\hline 135 & & & \\
\hline 138.5 & 8.02 & 93.60 & 57.58 \\
\hline 140 & 7.99 & 93.71 & 36.99 \\
\hline
\end{tabular}


Appendix C

Geophysical Logs 


\section{Appendix C}

\section{Geophysical Logs}

This appendix contains the high purity, germanium spectral gamma-ray log. The log was run by Waste Management Federal Services, Inc., Northwest and log data analysis completed by Three Rivers Scientific Company. Included with the log is a Log Header sheet, Acceptance QA Processing data, and a Log Analysis Summary Report. 


\section{RLS Spectral Gamma Ray Borehole Survey \\ Waste Management Federal Services NW}

\section{Log Header}

Project: $\quad$ RCRA Drilling - FY1998

Well: $299-$ W19 - 42

Log Type: $\quad$ HPGe Spectral Gamma Ray

Borehole Information

\begin{tabular}{|c|c|}
\hline Well ID $\quad$ B8553 & Water Depth $\underline{220.3}$ \\
\hline Elevation Reference Ground & Elevation \\
\hline Depth Reference Ground Surface & Casing Stickup $\underline{0.86 \mathrm{ft} 1^{\mathrm{st}}} \log \underline{0.6 \mathrm{ft}} 2^{\text {nd }} \log$ \\
\hline Casing Diameter 8 in $1^{\text {st } \log }$ & Depth Interval 0 to $136.9 \mathrm{ft}$ Thickness \\
\hline $\begin{array}{l}\text { Casing Diameter } \underline{8} \text { in } 2^{\text {nd }} \mathrm{Log} \\
\text { in }\end{array}$ & Depth Interval $\underline{0 \text { to } 265.7 \mathrm{ft}}$ \\
\hline
\end{tabular}

Logging Information

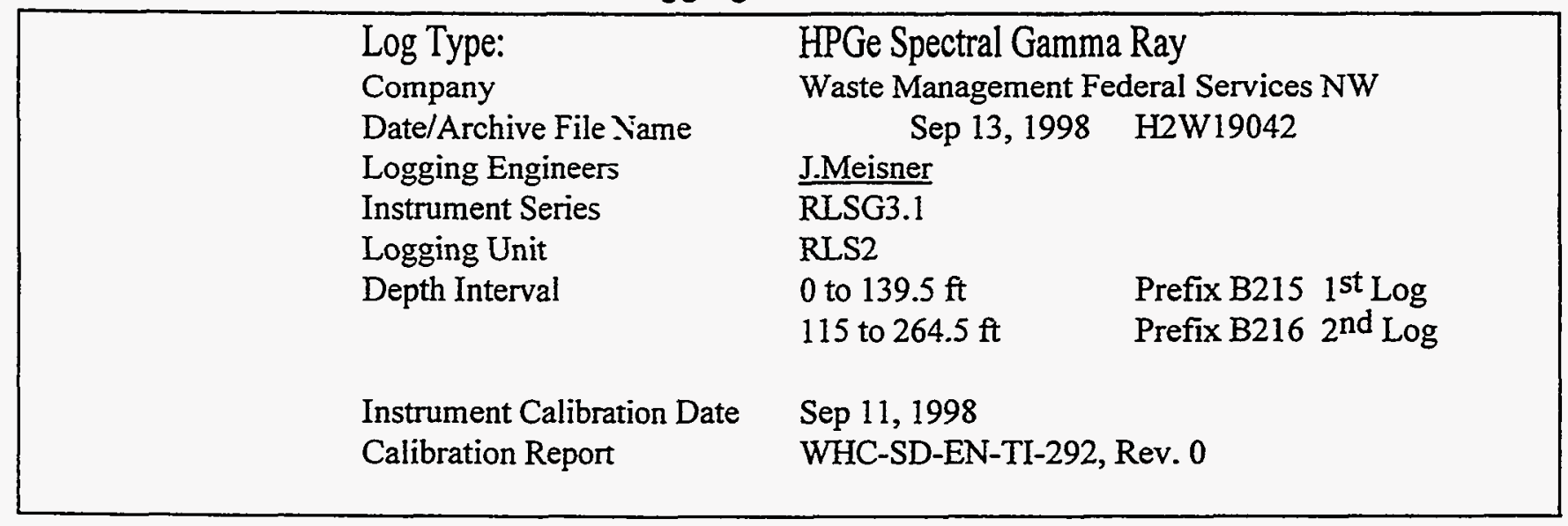

Analysis Information

$\begin{array}{ll}\text { Company } & \text { Three Rivers Scientific } \\ \text { Analyst } & \text { Russ Randall } \\ \text { Date } & \text { January 2,1999 }\end{array}$

Notes The only man made radionuclide detected is Cs-13 from surface to 10 feet. The maximum observed reading is $8.7 \mathrm{pCi} / \mathrm{g}$ at 1.25 feet. The $1^{\mathrm{st}} \mathrm{Log}$ was run at the end of the drilling with the 0.5 inch wall casing, and the $2^{\text {nd }} \log$ was run at total depth with the 0.312 inch wall casing. 


\section{RLS Spectral Gamma Ray Borehole Survey Waste Management Federal Services NW}

Project: RCRA Drilling - FY1998 Log Date: Sept. 9 \& 13, 1998 Borehole: 299-W19-42 (B8553) Naturally Occurring Radionuclides

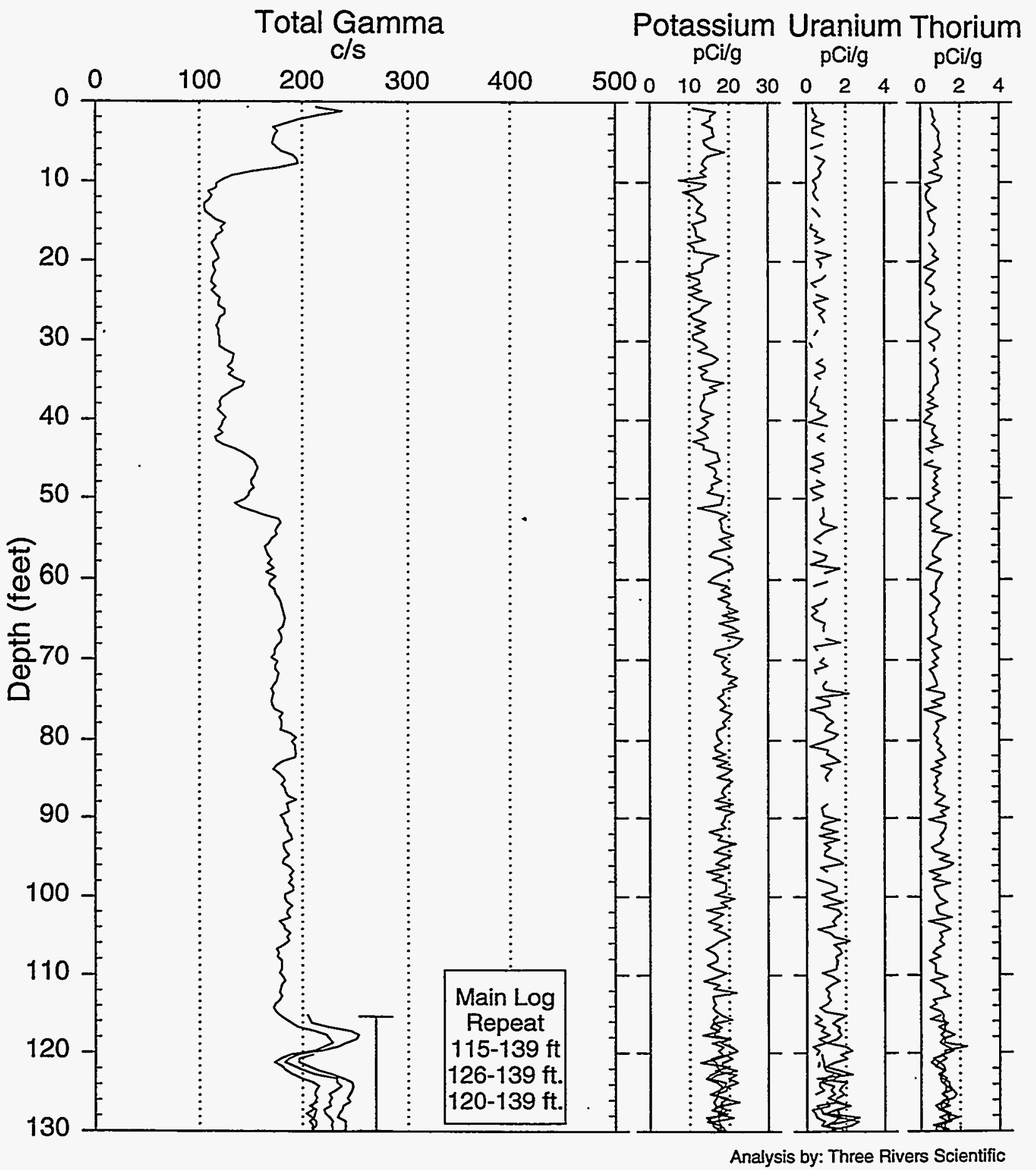




\section{RLS Spectral Gamma Ray Borehole Survey Waste Management Federal Services NW}

Project: RCRA Drilling - FY1998 Log Date: Sept. 9 \& 13, 1998 Borehole: 299-W19-42 (B8553) Naturally Occurring Radionuclides

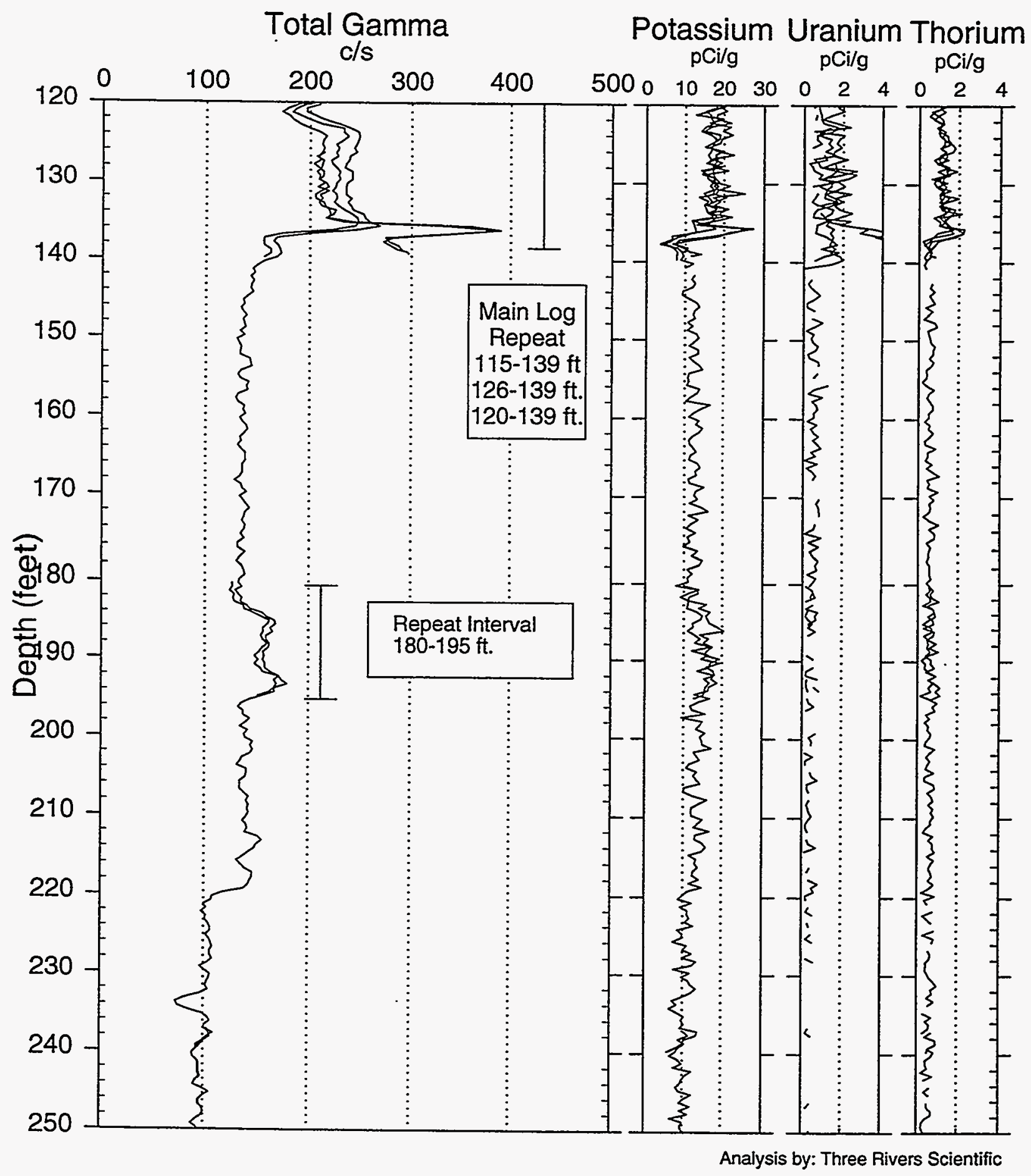




\section{RLS Spectral Gamma Ray Borehole Survey Waste Management Federal Services NW}

Project: RCRA Drilling - FY1998 Log Date: Sept. 9 \& 13, 1998 Borehole: 299-W19-42 (B8553) Naturally Occurring Radionuclides

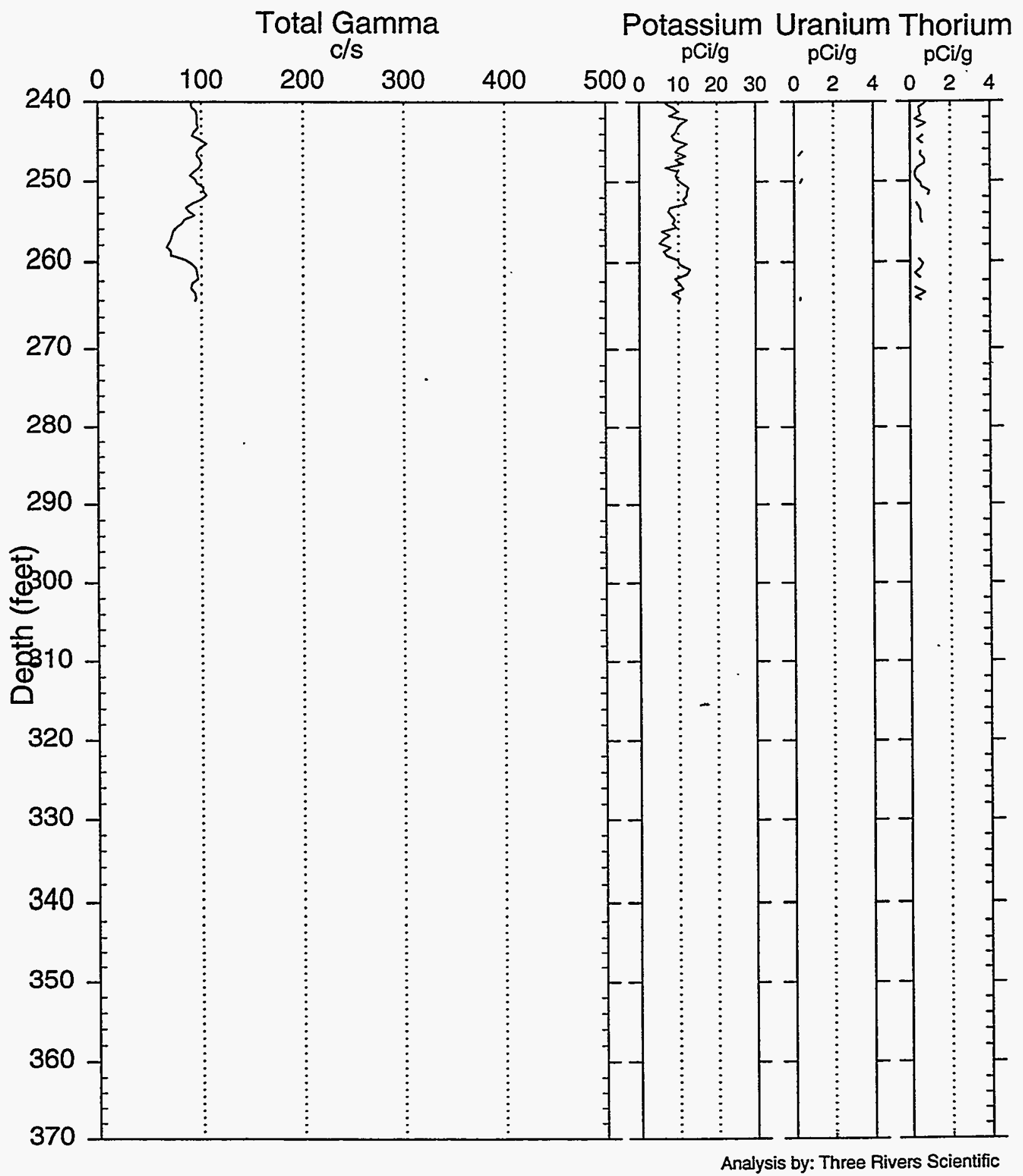


RLS Spectral Gamma-Ray Borehole Survey Waste Management Federal Services Inc., Northwest Operations

Project: RCRA Drilling - 98 Borehole : 299-W19-42
Log Date : September 9, 1998

Depth Datum: Ground Level

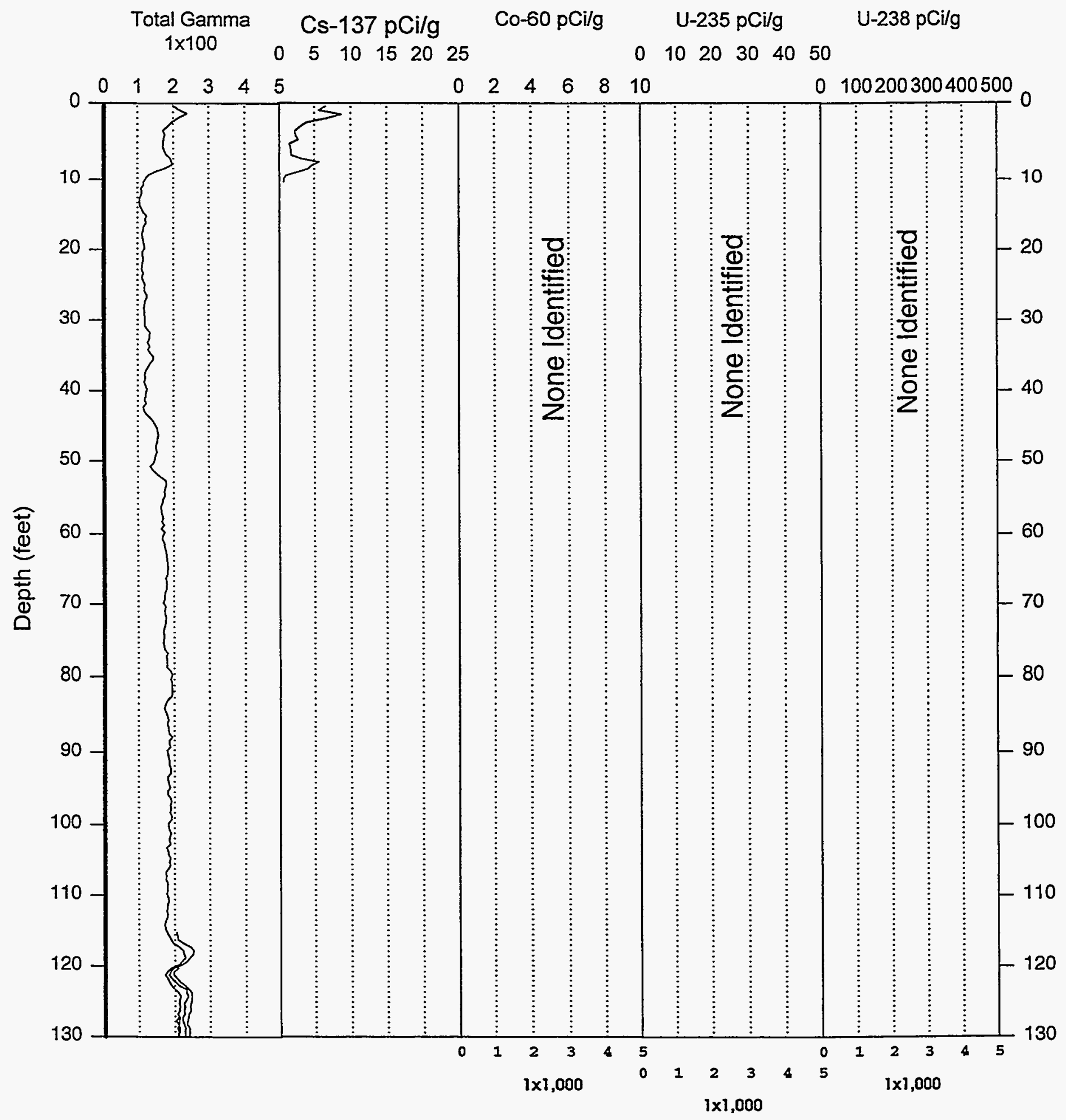

Analysis by: Three Rivers Scientific 


\section{RLS Spectral Gamma-Ray Borehole Survey}

Waste Management Federal Services Inc., Northwest Operations

Project: .RCRA Drilling - 98 Borehole : 299-W19-42
Log Date : September 9, 1998

Depth Datum: Ground Level

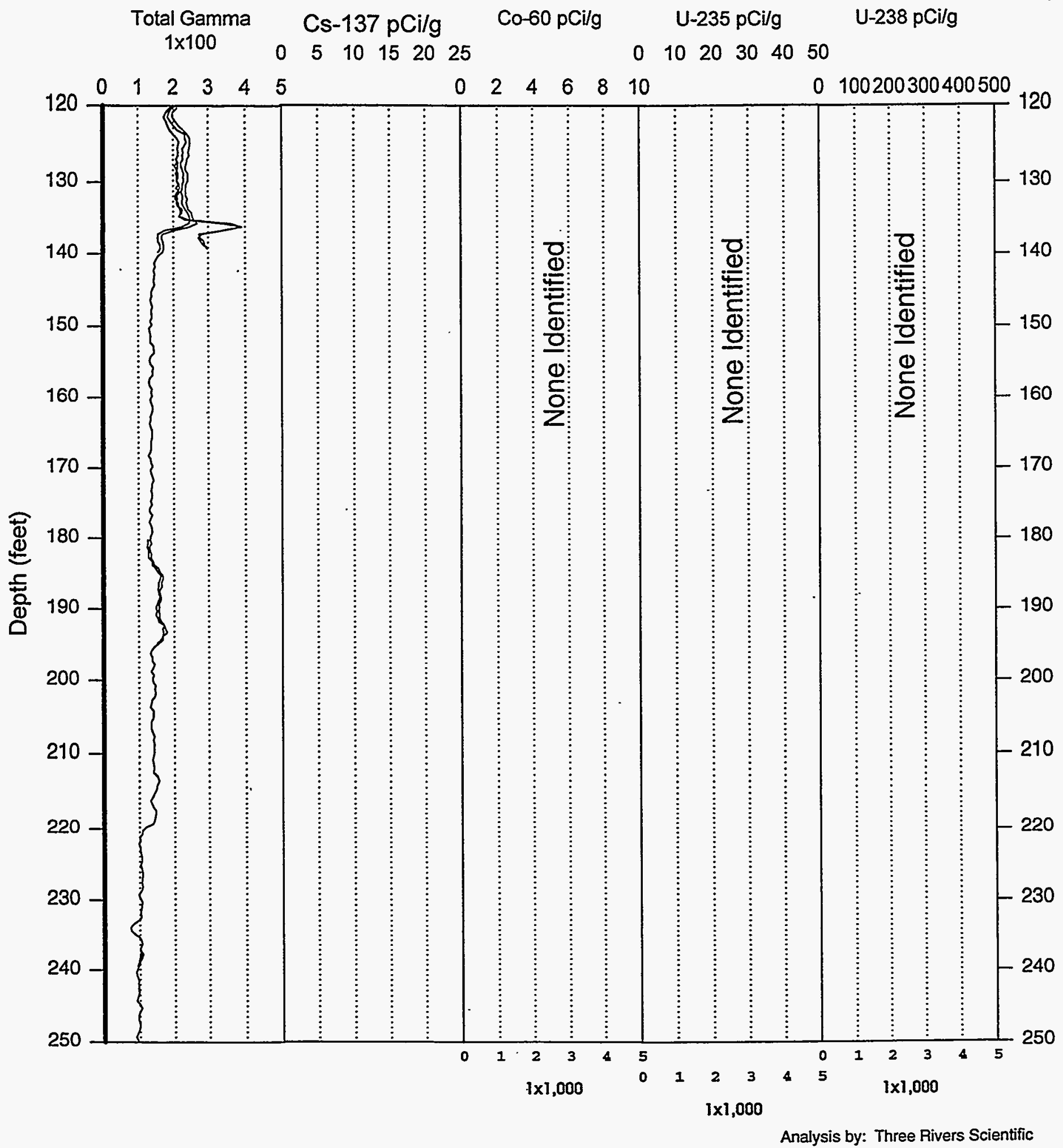


RLS Spectral Gamma-Ray Borehole Survey Waste Management Federal Services Inc., Northwest Operations

Project: RCRA Drilling - 98 Borehole : 299-W19-42
Log Date : September 9, 1998

Depth Datum: Ground Level

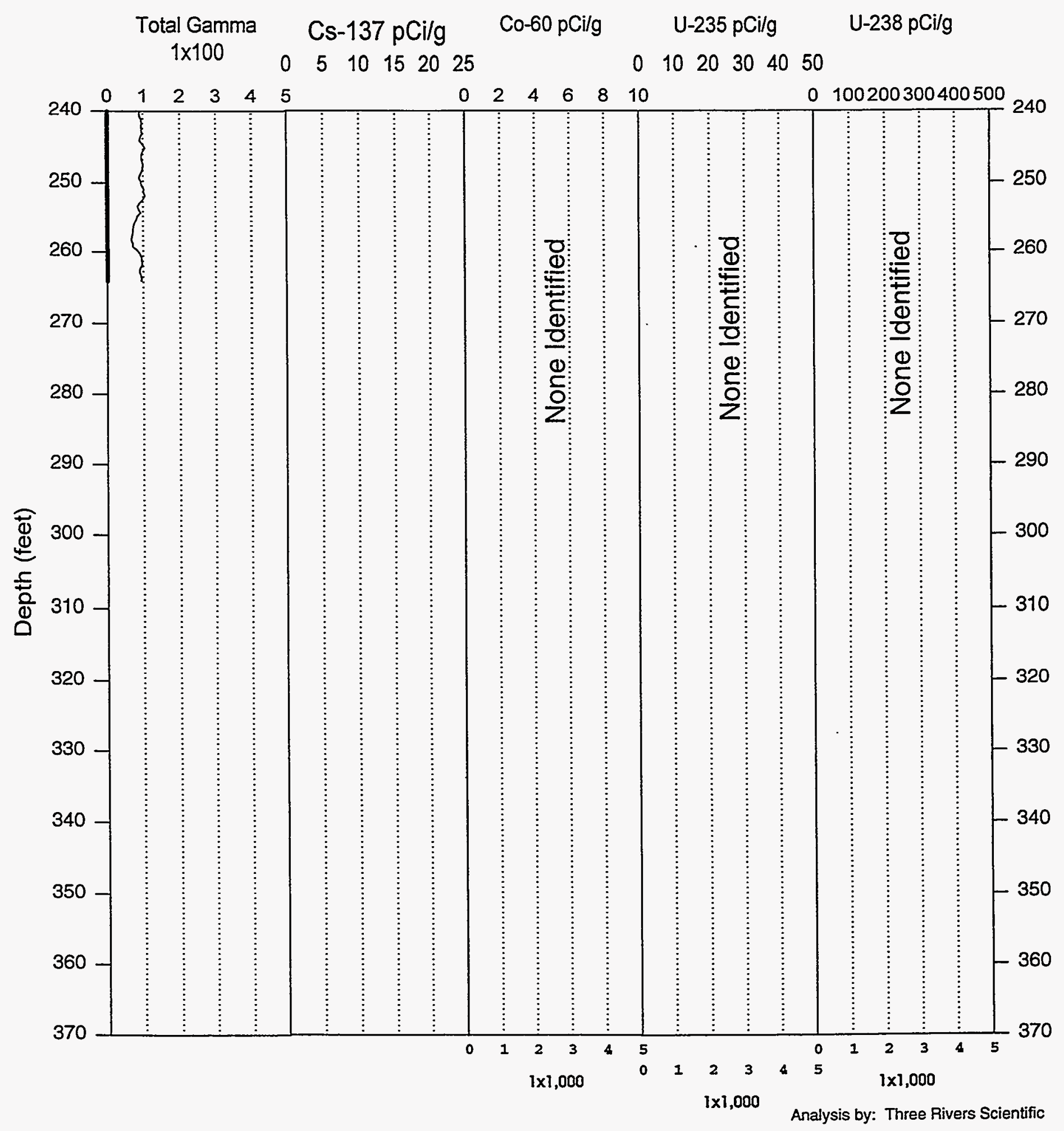


RLS Spectral Gamma Ray Borehole Survey

Acceptance QA Processing

Project: RCRA Drilling - FY1998 Log Date: Sep 9 \& 13, 1998

Borehole: 299-W19-42 (B8553) Compare Main Log \& Repeats

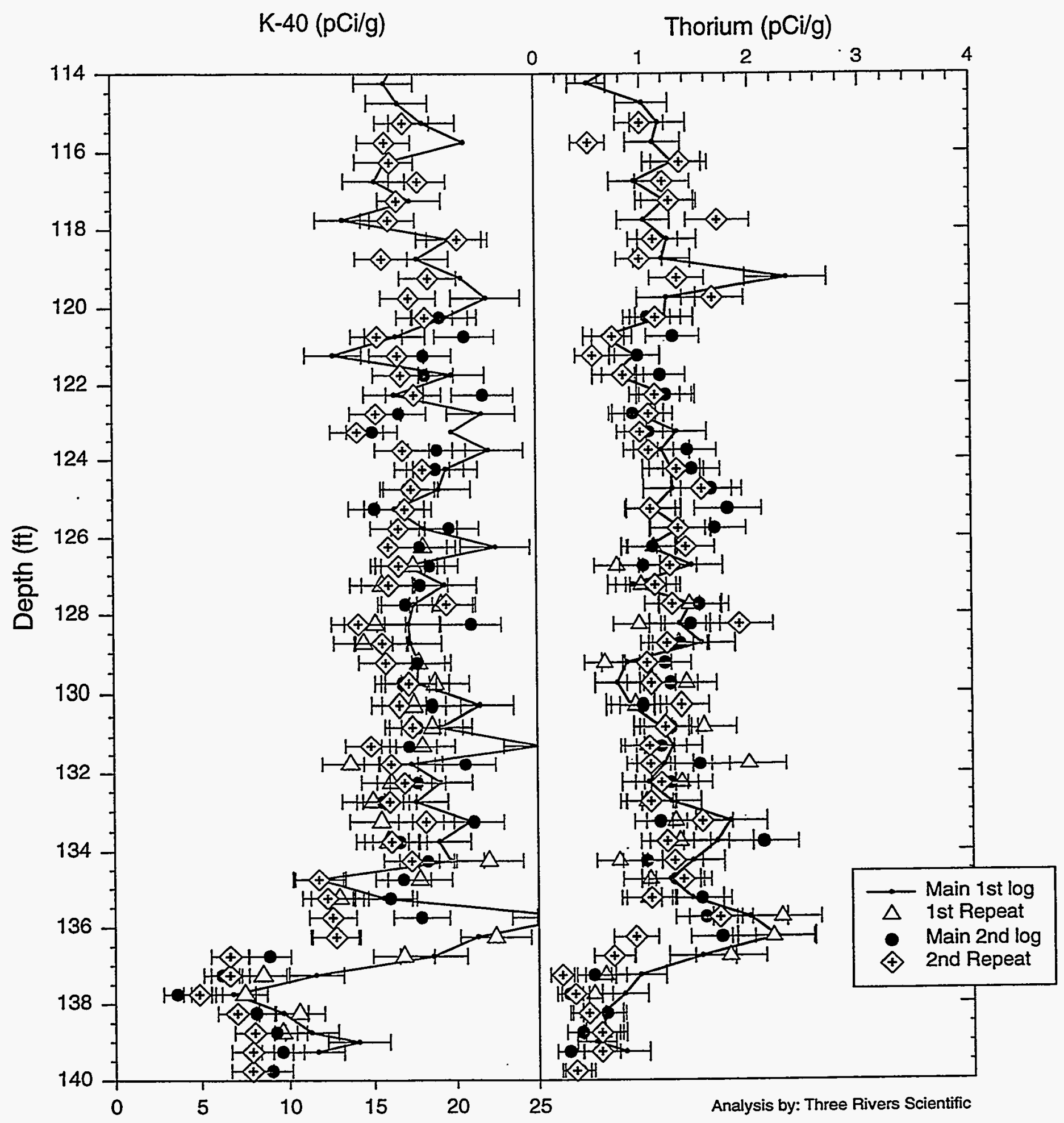




\section{RLS Spectral Gamma Ray Borehole Survey Acceptance QA Processing}

Project: RCRA Drilling - FY1998 Borehole: 299-W19-42 (B8553)
Log Date: Sep 9 \& 13, 1998 Compare 2nd Log \& Repeat

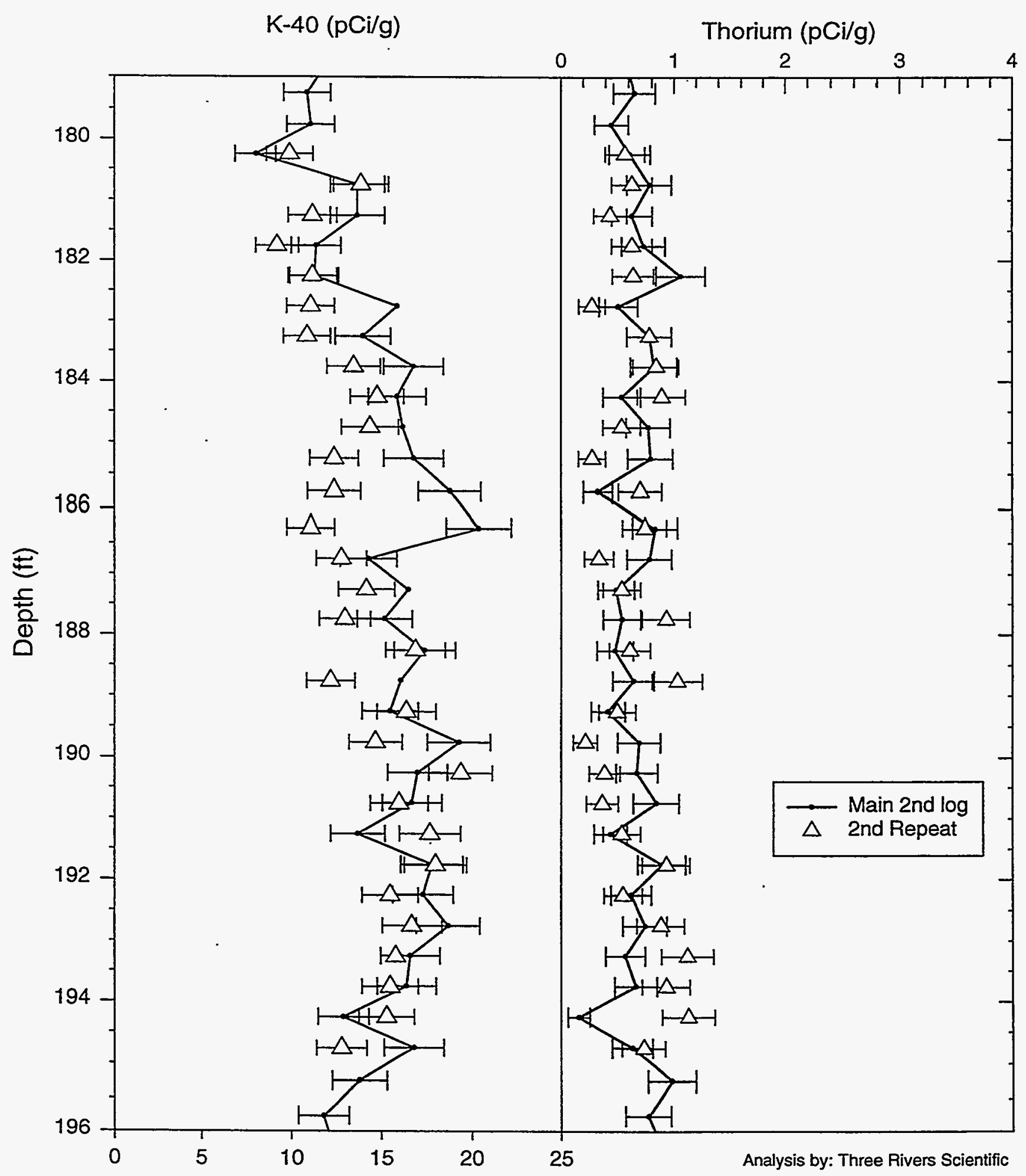




\section{RLS Spectral Gamma Ray Borehole Survey}

Waste Management Federal Services NW

\section{Log Analysis Summary Report}

$\begin{array}{lllr}\text { Project: } & \text { RCRA Drilling - FY1998 } & \text { Well ID: } & 299-\text { W19-42 } \\ \text { Log Type: } & \text { HPGe Spectral Gamma Ray } & \text { Log Dates: } & \text { Sep 9 \& 13, } 1998\end{array}$

\section{General Notes:}

Total gamma is a response to formation lithology for the entire depth logged below 10 feet, since a small level of Cs-137 exists from 0 to 10 feet.

The system dead-time limit was not exceeded (less than 5\%) for the borehole survey.

System Performance Verify: The pre- and post-log verifications were performed using coleman \#2 mantle, and passed the equipment performance check. The maximum FWHM for the $583 \mathrm{keV}$ gamma ray photo peak both the survey dates was $2.45 \mathrm{keV}$. The maximum acceptable FWHM resolution is $3.10 \mathrm{keV}$ for probe RLSG3.1 on these $\log$ dates.

Repeat Interval: The drilling of this well was changed from 0.5 inch wall caging to 0.312 inch wall casing after Sep 9,1998 . The depth interval reached with the 0.5 inch wall casing was 136.9 feet. Therefore, the repeat has two classes. First, the $1^{\text {st }} \log$ run on Sep 9, 1998 covered entire depth at this time ( 0 to 139.5 feet), and repeated over the lower interval from 126 to 139 feet. The $2^{\text {nd }} \log$ covered different casing, thus a relog \& repeat interval was chosen from 115 to 140 feet, as well as a repeat interval for the $2^{\text {nd }} \log$ of 180 to 195 feet.

Both intervals of repeat and the combination of repeat \& re-log demonstrate acceptable variances within statistical precision of the data, as can be seen in the Acceptance QA processing plots. Note that the potassium and uranium concentrations have been casing corrected for the different casing thickness used for the overlap intervals.

There are several observations concerning the character of the repeat nature for these logging passes. Radon pumping is observed between survey dates as well as the start and end of the second logging run on this well. The changes in uranium and gross are not accompanied by changes in the potassium or thorium. Also, on the $1^{\text {st }} \log$, the depth interval logged exceeded the casing depth and the instrument was observed to begin to drop out of casing. This caused an apparent rinse in the gross for this logging pass.

Environmental Corrections: The KUT concentrations have been corrected for casing attenuation (entire well) and water inside the casing (below 220.3 feet) for a centralized detector configuration. No casing correction was applied to the total gamma due to Compton downscatter interference.

\section{Radionuclides:}

The only man-made radionuclide detected is Cs-137 from 0 to 10 feet. The maximum observed reading is 8.7 $\mathrm{pCi} / \mathrm{g}$ at 1.25 feet. No other man-made readionuclides were detected, even using a factor 4 summing technique. 


\section{Distribution}

No. of

Copies

OFFSITE

T. Valero

Washington State Department of Ecology $13154^{\text {th }}$ Avenue

Kennewick, WA 99336

\section{ONSITE}

2 DOE Richland Operations Office

M. J. Furman (2)

H0-12

Bechtel Hanford Company

A. J. Knepp

H0-19

Fluor Daniel Northwest

F. M. Mann

$\mathrm{H} 0-22$
No. of

Copies

Lockheed Martin Hanford Company

E. A. Fredenburg

R1-04

18 Pacific Northwest National Laboratory

F. N. Hodges (5)

K6-81

G. R. Holdren

K6-81

D. G. Horton (2)

K6-81

S. P. Luttrell

K6-96

L. F. Morasch

K6-86

F. A. Spane, Jr.

K6-96

Information Release Office (7) 